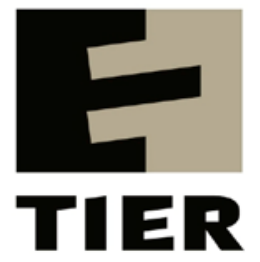

\title{
Horizontal Mismatch between Employment and the Field of Education: Evidence from a Systematic Literature Review
}

Melline A. Somers, Sofie J. Cabus,

Wim Groot \& Henriëtte Maassen van den Brink

TIER WORKING PAPER SERIES

TIER WP 16/02 


\title{
Horizontal Mismatch between Employment and the Field of Education: Evidence from a Systematic Literature Review ${ }^{1}$
}

\author{
Melline A. Somers ${ }^{23}$ Sofie J. Cabus ${ }^{4}$ Wim Groot $^{5}$ Henriëtte Maassen van den \\ Brink $^{6}$
}

Top Institute for Evidence Based Education Research

Maastricht University

The Netherlands

\begin{abstract}
This paper provides a systematic review of the growing literature on the poor match between employees' field degree and the job requirements, also referred to as horizontal mismatch. We identify the different definitions used in the literature and find that each measure of horizontal mismatch yields substantially different incidence rates. We discuss the validity of the different measures and conclude that a more uniform definition of horizontal mismatch is needed. The likelihood of horizontal mismatch is among other things determined by the extent to which employees possess general skills as opposed to occupation specific skills, and, it appears to be more frequently present among older workers. Compared to well-matched employees, horizontally mismatched workers generally incur a wage penalty, are less satisfied with their jobs, and are more likely to regret their study programme. The ensuing findings offer guidance to prevent horizontal mismatch as well as a roadmap for future research.
\end{abstract}

Keywords: labour market; skills; horizontal mismatch; field of education

JEL: I21; J24

\footnotetext{
${ }^{1}$ This study was financially supported by Stichting Instituut Gak. This foundation makes large-scale social policy research possible in the Netherlands. Stichting Instituut Gak was not involved in the preparation of the article.

${ }^{2}$ Top Institute for Evidence Based Education Research, TIER-Maastricht University, Kapoenstraat 2, 6211 KW Maastricht, the Netherlands (melline.somers@maastrichtuniversity.nl).

${ }^{3}$ Corresponding author.

${ }^{4}$ Top Institute for Evidence Based Education Research, TIER-Maastricht University, Kapoenstraat 2, $6211 \mathrm{KW}$ Maastricht, the Netherlands (s.cabus@maastrichtuniversity.nl).

${ }^{5}$ Top Institute for Evidence Based Education Research, TIER-Maastricht University, Kapoenstraat 2, 6211 KW Maastricht, the Netherlands (wn.groot@maastrichtuniversity.nl).

${ }^{6}$ Top Institute for Evidence Based Education Research, TIER-Maastricht University, Kapoenstraat 2, $6211 \mathrm{KW}$ Maastricht, the Netherlands (h.maassenvandenbrink@maastrichtuniversity.nl).
} 


\section{Introduction}

A good match between labour supply and labour demand is indispensable for graduates and companies and, consequently, for the economy as a whole. Job mismatches can have serious consequences, not only for the individual because of unemployment risks (http://ec.europa.eu/social); wage penalties (Groot \& Maassen van den Brink, 2000); or job dissatisfaction (McGuinness \& Sloane, 2011); but also for society. Education is an expensive investment that society makes through public investments in education (Levin, Belfield, Muennig \& Rouse, 2007; Levin \& Rouse, 2012). The highest return to this investment for society is obtained when individuals are well-matched to employers, such that knowledge acquired through education and on-the-job training is optimally utilized on the labour market. Mismatched employees may be less productive than they would have been in a job that allows them to fully deploy their skills. Moreover, as a result of job dissatisfaction, mismatched employees may exhibit counterproductive behaviour on the job through higher absence and quit rates (Büchel, 2002; Tsang, 1987). Suboptimal productivity may lead to wage penalties which, in turn, reduce the return to public investments in education (Quintano, Castellano \& D'agostino, 2008; McGuinness \& Sloane, 2011; Zhu, 2014). From an economic point of view, job mismatch is not optimal for society as we pay a 'social price' for job mismatches. These costs may pertain to foregone returns to public investments in education, but also to unemployment allowances and reduced revenues.

Mismatch between labour supply and labour demand can take different shapes and is usually measured by comparing employees' acquired education with the educational requirements of the job. Acquired education and educational requirements can be expressed in terms of the level or quantity of education. Workers who have attained more schooling than required are considered to be over-educated, whilst employees with less schooling than required are defined as being under-educated. This type of mismatch is also referred to as vertical mismatch (Heijke, Meng \& Ris, 2003). The incidence, determinants and consequences of vertical mismatch have been well-documented (see e.g., Alba-Ramirez, 1993; Chevalier, 2003; Chevalier \& Lindley, 2009; Dolton \& Silles, 2008; Dolton \& Vignoles, 2000; Duncan \& Hoffman, 1981a; Groeneveld \& Hartog, 2004; Kiker, Santos \& de Oliveira, 1997; McGuinness \& Bennett, 2007; Verdugo \& Verdugo, 1989; Verhaest \& Omey, 2006), and various studies have provided useful 
summaries of this stream of literature by means of reviews as well as meta-analyses (e.g., Groot \& Maassen van den Brink, 2000; Hartog, 2000; McGuinness, 2006; Rubb, 2003; Sloane, 2003). Research has confirmed the adverse outcomes associated with vertical mismatch and various hypotheses have been proposed to explain what determines the incidence of vertical mismatch and its consequences to persist.

During the past two decades, the concept of mismatch has been broadened to include the type or field of education as a source of mismatch. A situation in which employees' attended field of education is unrelated to the field required for the job is referred to as horizontal mismatch (Robst, 2007a). ${ }^{7}$ This type of mismatch is of special relevance as employees are not solely matched based on their level or quantity of education. Given that particular fields of education aim to prepare students for a range of occupations, matching job requirements with employees' field-specific skills is essential for an efficiently functioning labour market. Moreover, students are assumed to make their schooling choices based upon educational preferences and with the expectation of finding future employment in field-related occupations (Betts, 1996; Holland, 1985). As such, horizontal mismatch can be considered undesirable and result in an underutilization of skills. Although attending a field that fits individuals' interests plays an important role in motivating and preventing young students from dropping out of school (Spady, 1970), many graduates end up having a job that does not match their educational qualifications. At the same time, skill shortages are repeatedly reported by specific sectors across various OECD countries (e.g., Enequist et al., 2006; De Jong \& Berger, 2006; Smyth et al., 2006). ${ }^{8}$ One potential explanation for the presence of skill shortages is that too many students choose to study subjects that do not correspond to the labour market demand (Machin \& McNally, 2007). And although the U.S. Census Bureau shows that many graduates obtain a degree in fields that do offer good career prospects, a substantial share of these graduates still end up in jobs unrelated to the field of study ("Where do college graduates work?", 2014).

Considering the potential economic losses associated with an underutilization of skills, from a human capital theory perspective, horizontal mismatch is an undesirable phenomenon. Given that a proper allocation of skills on the labour market is in the best interest of society, an

\footnotetext{
${ }^{7}$ Instead of referring to horizontal mismatch, some studies simply refer to the match between an employee's field degree and his/her job. In this study we will use both terms.

${ }^{8}$ According to the OECD's review of tertiary education, shortages are often reported in the health care and engineering sectors. Likewise, the Employers Skill Survey conducted in the UK indicates a shortage of science, mathematics and engineering graduates (McIntosh, 2005).
} 
important question to be raised is how prevalent mismatch is and what are the welfare losses generated by horizontal mismatch. We address these questions through four sub questions: (1) How is horizontal mismatch defined and measured? (2) To what extent is horizontal mismatch observed? (3) What are the determinants of horizontal mismatch? And (4) What are the consequences of horizontal mismatch? We answer these questions by means of a systematic review of the literature on mismatch between employees' job and the attended field of education. In particular the third question allows us to develop policy recommendations to prevent and reduce horizontal mismatch. The objective of this paper is to present an integrated summary of the existing body of knowledge of horizontal mismatch. We identify where the conclusions of previous research converge and diverge and set the agenda for future research.

This paper proceeds as follows. Section 2 describes the literature search strategy. In Section 3 we address how horizontal mismatch has been defined and measured in the literature and what the advantages and drawbacks are of these definitions. Section 4 discusses the incidence of horizontal mismatch and Section 5 addresses the determinants of horizontal mismatch. In Section 6 we discuss the consequences of mismatch between the field degree and employees' job. Finally, Section 7 discusses the main conclusions of this study and provides suggestions for future research.

\section{Method}

For our review, we set a series of inclusion criteria to narrow the extensive body of research down to a manageable set of studies for a thorough analysis: (1) The study is published between 1995 and 2015 in peer-reviewed academic journals in the Dutch or English language. (2) Empirical studies are included, whereas theoretical, conceptual and case studies are excluded. Potential empirical studies encompass descriptive, correlational as well as causal (experimental) studies. (3) The study has to deal with a mismatch between the employees' job and the attended field of education. Studies that focus on other types of mismatch (e.g. over- and under-education) were not retained.

We limit our literature search to the time window 1995-2015 as concerns about horizontal mismatch were first raised in 1995 by Witte and Kalleberg. Prior to the publication of this paper, studies on education-job mismatch only focused on employees' attained level of education. Furthermore, our systematic review is restricted to publications in the Dutch or 
English language due to a lack of resources and facilities for translation. ${ }^{9}$ Moreover, we only consider empirical articles published in academic journals and therefore exclude non empirical studies such as qualitative research methods based on interviews, case studies or conceptual work, but also studies published on the internet, in books or in other non-peer reviewed journals. This provides us with a better comparable body of research which improves the quality of our systematic literature review. Finally, given that we explore whether a mismatch between job requirements and the skills acquired through the field of study contributes to an inefficient allocation of skills on the labour market, we restrict our search to studies focusing on horizontal mismatch. Therefore, we exclude studies that concentrate on other types of mismatch such as under-education and over-education, as these do not answer our main research question and have already been well-documented in other reviews (e.g., Groot \& Maassen van den Brink, 2000; Hartog, 2000).

We performed a computerized systematic search using a wide range of search terms or keywords, namely, "mismatch", "match" or "fit" combined with "education", "study", "major", "programme", "program" or "college” and "job", “employment”, “work”, “occupation”, "labour” or "labor" and "field" (see Appendix 2. for the exact combination of search terms). The search was conducted in the following electronic databases: ERIC, EconLit and SocINDEX. ERIC is used as the main search engine as it is the largest education database worldwide, providing access to about 1000 scientific journals. EconLit and SocINDEX were used in order to add potentially missing articles to our search results. Figure 1 provides an overview of the selection process of relevant studies.

ERIC initially provides 424 studies that were published between January 1995 and December 2015, whereas EconLit and SocINDEX provide us with 99 and 237 potential records, respectively. Excluding the duplicated, non-peer-reviewed, non-English and non-Dutch records leaves us with 378 studies. Consequently, the studies were sorted based on the title and abstract which further allowed us to exclude 354 studies that did not meet our inclusion criteria. Reading

\footnotetext{
${ }^{9}$ We recognize that this restriction potentially introduces language bias as studies conducted in non-English speaking countries are more likely to be published in an international English-language journal when significant results are found (Egger et al., 1997b; Moher et al., 1996). However, the problem of language bias has been reduced in the recent years due to the shift toward publication of studies in the English language (Galandi, Schwarzer \& Antes, 2006). As can be seen in Appendix 1, the majority of the records we consider for our review have been published after 2000 and we therefore consider the problem of language bias to be minimal.
} 
the articles' full text, we keep 24 relevant papers.

Table 1 presents the selected studies and provides an overview of the data that were extracted: the year of publication, the number of countries included, the type of data, the year of data collection, the type of study, the sample size, and, the determinants and effects examined. As can been seen in Table 1, the studies selected for our review have several noticeable characteristics. Most studies on horizontal mismatch have been published recently, namely, after 2010. The majority of studies included in our review are correlational and make use of crosssectional data, whereas no studies were causal or experimental in nature. The mismatch determinants that were subject to examination in the reviewed studies can be categorized into four major clusters: education-related, labour market-related, job-related and individual-related determinants. The first cluster can be further categorized into education-related determinants on the individual level and on the country level. Concerning the effects of horizontal mismatch, the emphasis has been on employees' wages in most studies.

Figure 1. The selection process

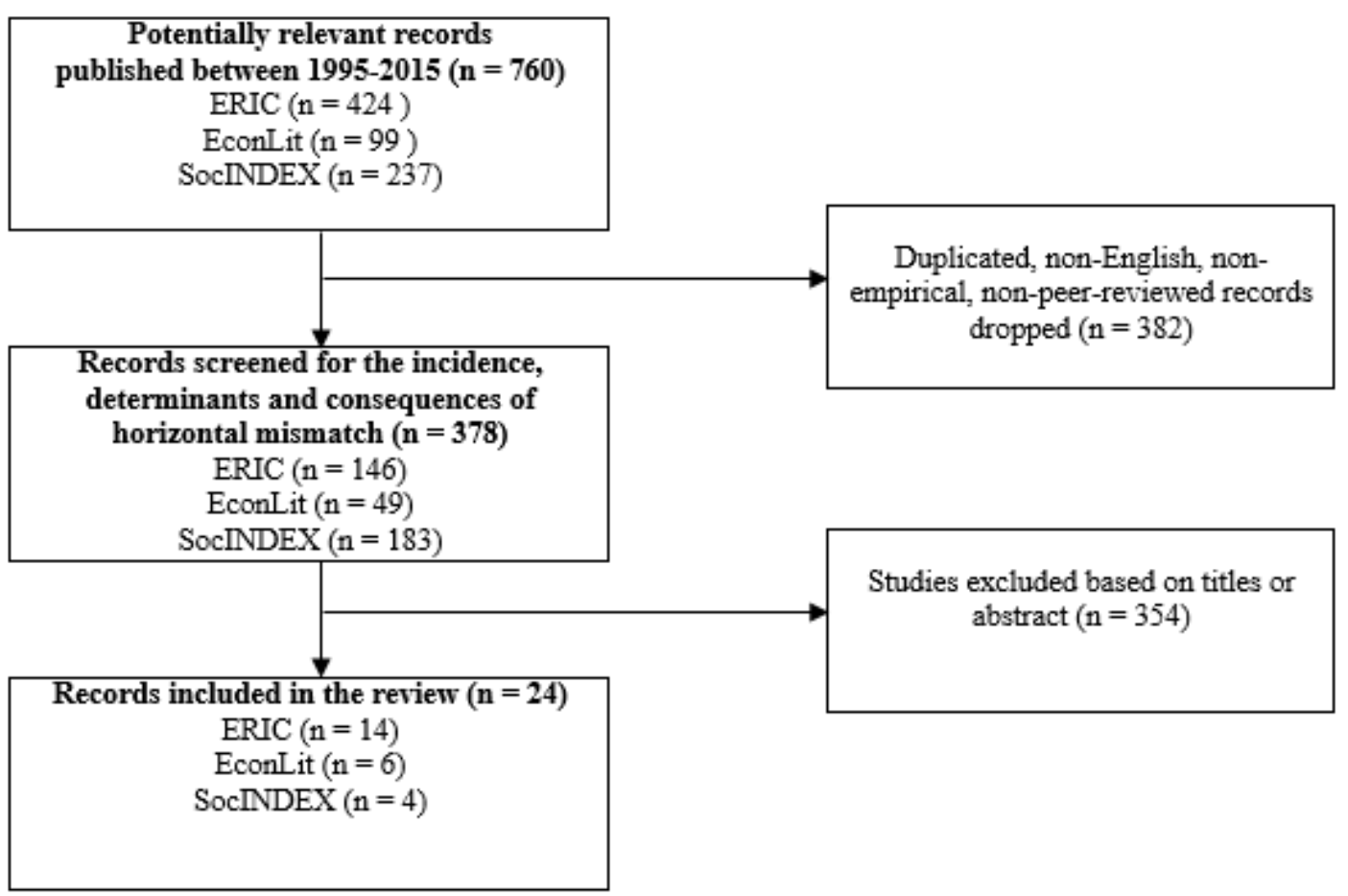


Table 1. General Description of Publications Included in the Analysis (24 publications reviewed)

\begin{tabular}{|c|c|c|c|}
\hline $\begin{array}{l}\text { Classification } \\
\text { category }\end{array}$ & Sub-categories & $\mathrm{N}$ & Reference index in Appendix 1 \\
\hline \multirow[t]{4}{*}{ Year of publication } & $1995-2000$ & 1 & 1 \\
\hline & $2001-2005$ & 3 & $2,3,4$ \\
\hline & $2006-2010$ & 8 & $5,6,7,8,9,10,11,12$ \\
\hline & $2011-2015$ & 12 & $13,14,15,16,17,18,19,20,21,22,23,24$ \\
\hline \multirow[t]{2}{*}{$\begin{array}{l}\text { Number of countries } \\
\text { included in the study }\end{array}$} & Single country & 18 & $\begin{array}{l}1,2,3,5,6,7,8,10,11,12,13,14,15,17 \\
18,19,23,24\end{array}$ \\
\hline & Several countries & 6 & $4,9,16,20,21,22$ \\
\hline \multirow[t]{3}{*}{ Type of data } & Cross sectional data & 18 & $\begin{array}{l}1,2,4,5,6,9,10,11,13,16,17,18,19,20, \\
21,22,23,24\end{array}$ \\
\hline & Time series data & 4 & $3,7,8,15$ \\
\hline & Panel data & 2 & 12,14 \\
\hline \multirow{6}{*}{$\begin{array}{l}\text { Year of data } \\
\text { collection }\end{array}$} & $1980-1985$ & 2 & 1,12 \\
\hline & $1986-1990$ & 4 & $1,9,12,16$ \\
\hline & 1991-1995 & 5 & $3,5,6,12,14$ \\
\hline & $1996-2000$ & 5 & $2,4,7,10,14$ \\
\hline & 2001-2005 & 8 & $7,8,11,13,14,17,19,20$ \\
\hline & $2006-2011$ & 8 & $8,14,15,18,21,22,23,24$ \\
\hline \multirow[t]{3}{*}{ Type of study } & Descriptive & 1 & 8 \\
\hline & Correlational & 23 & $\begin{array}{l}1,2,3,4,5,6,7,9,10,11,12,13,14,15 \\
16,17,18,19,20,21,22,23,24\end{array}$ \\
\hline & Causal/experimental & 0 & \\
\hline \multirow[t]{7}{*}{ Sample size } & Less than 1,000 & 2 & 15,18 \\
\hline & $1,000-2,000$ & 1 & \\
\hline & $2,000-3,000$ & 3 & $1,2,12$ \\
\hline & $3,000-4,000$ & 2 & 9,10 \\
\hline & $4,000-5,000$ & 0 & \\
\hline & $5,000-10,000$ & 5 & $3,17,20,22,23$ \\
\hline & Greater than 10,000 & 11 & $4,5,6,7,8,11,13,14,16,19,21$ \\
\hline \multirow[t]{25}{*}{$\begin{array}{l}\text { Determinants subject } \\
\text { to examination }\end{array}$} & $\begin{array}{l}\text { Education related determinants - individual } \\
\text { level }\end{array}$ & & \\
\hline & Field of study & 9 & $4,5,6,7,14,15,17,18,22$ \\
\hline & Level of education & 8 & $4,5,6,7,15,17,18,19$ \\
\hline & Attending vocational education & 2 & 18,21 \\
\hline & Type of vocational education & 2 & 1,4 \\
\hline & Work experience during studies & 2 & 18,22 \\
\hline & Major activity before programme enrolment & 1 & 17 \\
\hline & Time devoted to studies & 2 & 15,17 \\
\hline & Study programme's prestige & 1 & 18 \\
\hline & $\begin{array}{l}\text { Education related determinants - country } \\
\text { level }\end{array}$ & & \\
\hline & Timing of academic specialization & 1 & 16 \\
\hline & Vocational orientation education system & 1 & 21 \\
\hline & Strength institutional linkages & 1 & 21 \\
\hline & Labour market related determinants & & \\
\hline & State economy & 2 & 4,7 \\
\hline & Job search duration & 1 & 22 \\
\hline & Opportunity structure & 1 & 1 \\
\hline & Job related determinants & & \\
\hline & Job tenure & 3 & $1,4,18$ \\
\hline & Occupational group & 3 & $1,15,19$ \\
\hline & Type of employment contract & 3 & $4,17,22$ \\
\hline & Sector & 2 & 4,14 \\
\hline & Firm size & 3 & $1,4,18$ \\
\hline & Occupational 'cultures of training' & 1 & 1 \\
\hline & Method to obtain employment & 1 & 17 \\
\hline
\end{tabular}




\begin{tabular}{|c|c|c|c|}
\hline & \multicolumn{3}{|l|}{ Individual related determinants } \\
\hline & Gender & 11 & $1,4,5,6,7,14,15,17,18,19,22$ \\
\hline & Age & 10 & $1,4,5,6,7,14,17,18,19,22$ \\
\hline & Ethnicity & 5 & $5,6,7,17,19$ \\
\hline & Disability & 3 & $5,6,14$ \\
\hline & Marital status & 3 & $5,6,19$ \\
\hline & Job mobility & 2 & 7,22 \\
\hline & Parental education & 2 & 17,22 \\
\hline & Ability & 2 & 17,18 \\
\hline Effects subject to & Wage & 13 & $1,2,3,5,6,9,11,12,13,14,19,23,24$ \\
\hline examination & On-the-job search & 5 & $2,4,9,13,24$ \\
\hline & Occupational status & 1 & 4 \\
\hline & Training participation & 1 & 4 \\
\hline & Job satisfaction & 5 & $2,9,13,19,24$ \\
\hline & Field of study regret & 2 & 10,20 \\
\hline
\end{tabular}

Note: studies can fall into more than one subcategory. a. An overview of the examined countries can be found in Appendix 1. The numbers in the last column of the table refer to 1 of the 24 studies for which more detailed information is provided in Appendix 1 .

\section{Measurement of Horizontal Mismatch}

Horizontal mismatch is usually defined by comparing an employee's attended field of study and the field required for the job the employee holds. The literature on horizontal mismatch distinguishes between 'subjective' and 'objective' definitions. The subjective approach measures the educational requirements for a job based on employees' self-report. The objective method, on the other hand, determines the educational requirements for an occupation using an expert or by assigning occupational codes for statistical purposes to educational fields.

\subsection{Subjective Measure}

In many subjective specifications of horizontal mismatch, the respondent specifies the job requirements in terms of the attended field of education. For instance, Kucel and Vilalta-Bufí (2013) classified employees as horizontally matched if s/he reported that exclusively the own attended field or a related field was appropriate for the job, whilst employees were classified as horizontally mismatched when a completely different field or no particular field was most appropriate for the job. Other studies based their definition on the degree to which employees perceive a fit between their field degree and their current job. An example of a question aiming at measuring this degree is: 'Thinking about the relationship between your work and your education, to what extent is your work related to your doctoral degree? Was it closely related, somewhat related, or not related?' (see for instance Bender \& Heywood, 2011; Bender \& Roche, 2013; Robst, 2007a; Robst, 2007b). 


\subsection{Objective Measure}

In addition to employees' self-assessment, several studies used an objective indicator of horizontal mismatch. Béduwé and Giret (2011) derived horizontal mismatch measures from a normative correspondence table established by experts and that depicts the match between occupations and the field and level of education. This table categorizes the distinct areas of vocational knowledge into 25 groups to which both educational qualifications and occupations can belong. When the knowledge group of the field degree and occupation do not correspond, there is 'horizontal mismatch'. Other studies use the International Standard Classification of Occupations to assign occupational codes to a field of study (e.g., Wolbers, 2003). The matching process is based on the extent to which the skills acquired through a specific field degree correspond to the job requirements. Accordingly, a discrepancy between the skills obtained in initial education and the skills needed on the job is considered as horizontal mismatch.

The potential advantage of the subjective approach is that it is specifically concerned with the content of the respondent's job and not with any type of aggregate of that occupation. In contrast, the normative correspondence table used by Béduwé and Giret (2011) allows occupations and educational qualifications to be categorized into only 25 groups. Some occupations or educational qualifications will better fit into one of the categories than others. Having too many categories, however, increases the likelihood that the combination of jobs and field degrees are defined as mismatched despite a large congruence of skills and knowledge (Malamud, 2011). Therefore, the subjective approach might provide a more valid measure of horizontal mismatch as employees' field degree is directly compared with the content or the educational requirements of the job. A potential disadvantage of the subjective method is that employees' perception of horizontal match is by definition subject to self-report bias. Two employees with the same educational background in similar jobs might have a different perception of the degree to which their job is related to their field of education. From this perspective, a method such as the normative correspondence table can provide a less biased indicator of horizontal mismatch. Moreover, asking employees whether their field degree was a requirement for the job might not be the best indicator for a mismatch between the skills acquired through the field degree and the job requirements. Some employers might simply require more general skills that can be obtained through various fields of study. Hence, the validity of these subjective measures can be called into question. 


\section{Prevalence of Horizontal Mismatch}

Table 2 summarizes the findings of the 20 studies that report the incidence of horizontal mismatch. Not all 24 studies selected for our review estimated the prevalence of horizontal mismatch. The literature identifies at least four ways to measure horizontal mismatch: definition A - based on employees' assessment of whether a specific field of education was required for the job or not; definition B - based on employees' assessment of whether their attended field of education is related to or relevant for their current occupation; definition $\mathrm{C}$ - respondents' assessment of whether or not they have been trained for their current job; and definition D based on an objective evaluation where occupations and educational fields are categorized according to the assumed congruence between the skills acquired through the field degree and the skills needed to perform a specific occupation.

Table 2 shows that there is considerable variation in the mismatch incidence reported by the studies under review. Note that some studies made a distinction between severely mismatched and moderately mismatched employees when reporting the incidence rate of mismatched employees (e.g., Robst, 2007a; Robst, 2007b), whereas other studies combined such categories into one (e.g., Allen \& van der Velden, 2001). ${ }^{10}$ The incidence reported by the studies under review vary from 7 to 63 percent. The incidence, however, seems to depend on how horizontal mismatch is specified. For instance, Malamud (2011) found 63 percent of employees in England to be mismatched when using a narrow classification and an incidence rate of 44 percent based on a very broad classification. Whilst the narrow classification allows fields and occupations to be categorized into 42 categories, the very broad classification distinguishes 6 categories. Hence, employees are more likely to be defined as mismatched according to the narrow classification.

On average, studies using definition A find that almost 21 percent of the employees are horizontally mismatched. According to definition B, 21.8 percent of the employees hold a field degree that is either only somewhat relevant or only slightly relevant for the job they hold (column 4). Based on the same definition, 23.3 percent of the employees hold a degree that is either somewhat relevant or completely irrelevant for their job (column 5). One study used

\footnotetext{
${ }^{10}$ As will be shown in Section 5 and 6, some studies choose to estimate the effects of the somewhat mismatched and severely mismatched categories separately (e.g., Bender \& Roche, 2011), whereas other studies choose to combine categories to create a dichotomous outcome variable for horizontal mismatch (e.g., Farooq, 2011). This possibly affects the results of these studies.
} 
definition $\mathrm{C}$ and found that 46 percent of the employees are in a job for which they have not been trained. Finally, according to definition D, 22.1 percent of the employees hold an occupation for which their field has some relevance (column 4). Again adopting definition D, column 5 shows that 35.4 percent of the employees are fully mismatched or hold a degree that only has low relevance for their job.

According to the studies that distinguish between genders, there does not appear to be a clear pattern in favour of men or women with respect to finding a matching job. Furthermore, Bender and Heywood (2011) found that the prevalence of horizontal mismatch is greater among employees in the middle or late stage of their career than among employees early in their career. The share of graduates experiencing horizontal mismatch also differs per country. Moreover, the extent to which employees are mismatched based on their field of study varies between different types of employment. Horizontal mismatch appears to be present more often among selfemployed employees than among employees in a wage or salary job (Bender \& Roche, 2013). Finally, the reason for being horizontally mismatched differs across employees (Robst, 2007a; Robst, 2007b; Bender \& Heywood, 2011). Whilst a large share of employees reports to be mismatched because a job in a related field was unavailable, a substantial proportion of employees also accepts horizontal mismatch for pay or promotion opportunities or because of a change in career interests. 
Table 2. Incidence of Horizontal Mismatch

\begin{tabular}{|c|c|c|c|c|c|c|}
\hline $\begin{array}{l}\text { Author (year of } \\
\text { publication) }\end{array}$ & $\begin{array}{l}\text { Country of stuc } \\
\text { and definition }\end{array}$ & & $\begin{array}{l}\text { Year data } \\
\text { collection }\end{array}$ & $\begin{array}{l}\text { Moderately mismatched } \\
(\text { male/female) }(\%)\end{array}$ & $\begin{array}{l}\text { Severely mismatched (male/female) } \\
(\%)\end{array}$ & $\begin{array}{l}\text { Incidence of horizontal mismatch for } \\
\text { other sample characteristics }\end{array}$ \\
\hline Witte et al. (1995) & Germany & $\mathrm{C}$ & 1984-1990 & & Not trained for job: $46.35(51.0 / 39.0)$ & \\
\hline Allen et al. (2001) & $\begin{array}{l}\text { The } \\
\text { Netherlands }\end{array}$ & A & 1998 & & $\begin{array}{l}\text { Own/related field not most } \\
\text { appropriate: } \pm 20.0\end{array}$ & \\
\hline $\begin{array}{l}\text { Robst }(2007 a \\
2007 b)^{b}\end{array}$ & United States & B & 1993 & $\begin{array}{l}\text { Somewhat related: } 25.1 \\
(28.3 / 20.8)\end{array}$ & Not related: $20.1(19.1 / 21.4)$ & $\begin{array}{l}\text { Most important reason for accepting } H M \\
\text { (male/female) (\%): } \\
\text {-Pay, promotion: } 32.7 / 18.8 \\
\text {-Working conditions: } 8.8 / 11.1 \\
\text {-Job location: } 4.3 / 3.5 \\
\text {-Change career interests: } 19.0 / 19.3 \\
\text {-Family-related: } 5.9 / 18.1 \\
\text {-Job in field degree unavailable: } \\
16.0 / 16.3\end{array}$ \\
\hline Hensen et al. (2009) & $\begin{array}{l}\text { The } \\
\text { Netherlands }\end{array}$ & $\mathrm{B}$ & $1996-2001$ & & $\begin{array}{l}\text { Own/related field not most } \\
\text { appropriate: } 30.0(29.0 / 30.0)\end{array}$ & \\
\hline Mora $(2010)$ & Spain & $\mathrm{A}$ & 2000 & & No specific field required: 18.95 & \\
\hline Nordin et al. (2010) & Sweden & $\mathrm{D}$ & 2003 & $\begin{array}{l}\text { Weak match: } 11.67 \\
(18.0 / 8.0)\end{array}$ & Mismatch: $19.2(23.0 / 17.0)$ & \\
\hline Yakusheva (2010) & United States & $\mathrm{D}$ & $\begin{array}{l}1980,1984 \\
1986,1992\end{array}$ & $\begin{array}{l}\text { Knowledge associated } \\
\text { with field has medium } \\
\text { relevance for job: } 32.45\end{array}$ & " low relevance ": 14.55 & \\
\hline $\begin{array}{l}\text { Béduwé et al. } \\
(2011)\end{array}$ & France & $\mathrm{D}$ & 2001 & & 59.0 & $\begin{array}{l}\text {-No VM but HM: } 30 \\
\text {-VM and HM: } 29\end{array}$ \\
\hline Bender et al. (2011) & United States & B & $\begin{array}{l}1993,1995, \\
1997,1999, \\
2001,2003, \\
2006\end{array}$ & $\begin{array}{l}\text { Somewhat matched: } 24.7 \\
(25.5 / 22.5)\end{array}$ & Severely mismatched: $8.0(8.3 / 7.0)$ & $\begin{array}{l}\text {-Somewhat matched in early career: } 22.8 \\
\text {-" in middle ": } 25.3 \\
\text {-" in late ": } 26.8 \\
\text {-Severely mismatched in early career: } 5.9 \\
\text {-" in middle ": } 8.5 \\
\text {-" in late ": } 10.2 \\
\text { Most important reason for accepting } H M \\
\text { (early career/late career stage) (\%): } \\
\text {-Pay, promotion: } 22.1 / 19.3 \\
\text {-Working conditions: } 5.1 / 4.9 \\
\text {-Job location: } 4.6 / 5.2 \\
\text {-Change career interests: } 25.6 / 38.9 \\
\text {-Family-related: } 8.1 / 4.6 \\
\text {-Job in field degree unavailable: } \\
\text { 26.7/18.3 }\end{array}$ \\
\hline
\end{tabular}


Table 2 continued

\begin{tabular}{|c|c|c|c|c|}
\hline Farooq (2011) & Pakistan & $\begin{array}{ll}\text { B } & 2006 / 2007, \\
& 2008 / 2009\end{array}$ & $\begin{array}{l}\text {-Slightly relevant: } 13.8 \\
(18.5 / 12.9)\end{array}$ & -Irrelevant: $11.3(14.8 / 10.6)$ \\
\hline $\begin{array}{l}\text { Malamud (2010, } \\
2011)^{b}\end{array}$ & $\begin{array}{l}\text { England and } \\
\text { Scotland }\end{array}$ & $\begin{array}{l}\mathrm{D} \\
\mathrm{c}\end{array} 2011$ & & $\begin{array}{l}\text { Overall average: } 45.17 \\
\text {-Very broad classification England: } \\
44.0 \\
\text {-Broad classification England: } 50.0 \\
\text {-Narrow classification England: } 63.0 \\
\text {-Very broad classification Scotland: } \\
29.0 \\
\text {-Broad classification Scotland: } 34.0 \\
\text {-Narrow classification Scotland: } 51.0\end{array}$ \\
\hline $\begin{array}{l}\text { Boudarbat et al. } \\
\text { (2012) }\end{array}$ & Canada & B 2005 & & Somewhat/not closely related: 35.1 \\
\hline Kucel et al. (2012) & Poland & A 2008 & & Other/ no specific field required: 18.0 \\
\hline Kucel et al. (2013) & $\begin{array}{l}\text { Spain and } \\
\text { The } \\
\text { Netherlands }\end{array}$ & A 2005 & & $\begin{array}{l}\text { Other/ no specific field required: } \\
\text {-Spain: } 27.0 \\
\text {-Netherlands: } 20.0\end{array}$ \\
\hline Bender et al. (2013) & United States & B 2003 & $\begin{array}{l}\text { Overall weighted } \\
\text { average: } 23.64 \\
\text {-Moderately mismatched } \\
\text { wage/salary employees: } \\
23.7(25.5 / 21.0) \\
\text {-Moderately mismatched } \\
\text { self-employed: } 23.3 \\
(24.0 / 21.5)\end{array}$ & $\begin{array}{l}\text { Overall weighted average: } 14.2 \\
\text {-Severely mismatched wage/salary } \\
\text { employees: } 13.3(13.2 / 13.5) \\
\text {-Severely mismatched self-employed: } \\
19.4(17.5 / 24.4)\end{array}$ \\
\hline Levels et al. (2014) & 20 countries $^{d}$ & $\mathrm{D}$ & & 38.8 \\
\hline Zhu (2014) & China & B 2008 & & Not related: $28.16(27.2 / 29.7)$ \\
\hline $\begin{array}{l}\text { Shevchuk et al. } \\
(2015)\end{array}$ & Russia & B 2011 & & $\begin{array}{l}\text { Job fully/mostly mismatches } 39.31 \\
(43.4 / 35.6)\end{array}$ \\
\hline
\end{tabular}

A. based on self-report of whether a specific field of education was required for the job B. based on respondents' assessment of the extent to which their attended field of is related to or relevant for their current occupation C. respondents' assessment of whether or not they have been trained for their current employment D. objective measure. b. Note that these are two separate studies using the same dataset, we therefore we report the incidence of horizontal mismatch found in these studies once. c. Occupations and fields of study are categorized according to three gradations of classification: narrow (42 categories), broad (12 categories) and very broad (6 categories). An employee is defined to be horizontally mismatched when the field and occupation fall into different categories. Most analyses are based on the broad classification, but are robust to alternative classifications. d. Austria, Belgium, Czech Republic, Germany, Denmark, Spain, Finland, France, Greece, Hungary, Ireland, Italy, Luxembourg, the Netherlands, Norway, Poland, Sweden, Slovenia, Slovak Republic and the UK. 


\section{Determinants of Horizontal Mismatch}

In this section, we report which variables were considered potential determinants of horizontal mismatch in the studies under review. We discuss whether the studies at hand found positive, negative or no relationship between horizontal mismatch and the explanatory variables. The findings are summarized in Table 4 and are categorized into education-, labour market-, job-, and individual-related determinants. The number of potential determinants examined by the studies under review is substantial. We limit our discussion to those determinants that have been investigated by at least two studies or to those determinants that were found to affect mismatch. The determinants that were subject to examination in only one study, but that were not found to influence mismatch, can be found in Appendix 1.

\subsection{Education Related Determinants}

Several factors predicting horizontal mismatch relate to the education the individual has received. The education-related factors can be classified at two levels; the individual level and the country level. With education-related determinants on the individual level we refer to factors that are rather a choice of the individual such as the field and level of education. In contrast, educationrelated determinants on the country level are rather exogenous to the individual and may for instance pertain to the vocational orientation of a country's education system.

\subsubsection{Education Related Determinants at the Individual Level}

The prevalence of horizontal mismatch among graduates depends among other things on the characteristics of the attended study programme such as the field and level of education, but also on the type of education. With respect to the field degree, the highest mismatch rates are found among liberal arts graduates, whilst the mismatch rates are lowest for graduates from health related fields (Robst, 2007a; Wolbers, 2003). Health related fields are characterized by providing students with occupation-specific skills which reduces the likelihood to search for jobs outside their own field (Wolbers, 2003). Mismatch can also be ascribed to a discrepancy between the supply and demand for graduates in a certain field. Cosser (2010) showed that whilst in South Africa the demand for graduates is mainly in the field of science, engineering and technology, most graduates have obtained a degree in the field of humanities. The field degree also interacts with the relation between mismatch and the career stage. This can be attributed to the pace of 
human capital depreciation associated with the field of study (Bender \& Heywood, 2001). For instance, science- and engineer-based careers are more sensitive to mismatch due to the high frequency of technological changes which induce rapidly changing skill requirements (Bender \& Heywood, 2001).

Besides the field degree, individuals' level of education predicts the likelihood of being horizontally mismatched. Employees who are not able to find a job that matches their level of education might compete with less-educated employees for a job below their level but in a related field (Borghans \& de Grip, 2000). Given that the less-educated face fewer jobs for which they can deploy this strategy, accepting a job in a different field is more likely to be an alternative strategy for this group when a matching job is unavailable. Several studies selected for our review support this hypothesis when comparing university graduates with different academic degrees, but also when comparing tertiary education graduates with upper secondary and post-secondary graduates (Bender \& Roche, 2013; Boudarbat \& Chernoff, 2012; Hensen, de Vries \& Cörvers, 2011; Robst, 2007a; Wolbers, 2003).

Although the level of education is negatively related to horizontal mismatch, at the same time, higher levels of education are often more general in nature. General skills lend themselves to a wider variety of jobs which positively affects one's chances to end up in a job not directly related to the field degree. Vocational programmes, on the other hand, provide students predominantly with occupation-specific skills, creating a stronger link between the field degree and the jobs for which students are being prepared. As such, school leavers with a vocational degree are more likely to be horizontally matched than graduates without a vocational training (Levels, van der Velden \& Di Stasio, 2014). ${ }^{11}$ Also the type of vocational system influences horizontal mismatch. Employers can substantially reduce selection and allocation costs by hiring graduates who received workplace-based or apprenticeship training in their organization (Wolbers, 2003). Hiring these graduates removes the need for screening and has the advantage of employing employees who already have acquired firm-specific skills. However, Wolbers (2003) did not find that workplace-based or apprenticeship training offered vocational graduates significant benefits in terms of finding a matching job compared to students with no vocational education.

\footnotetext{
${ }^{11}$ Levels et al. (2014) found that the strength of the relation between horizontal mismatch and having a vocational degree does not depend on the vocational orientation of a country.
} 
In addition to study programme characteristics, study-related as well as non-study related activities during one's studies can affect the chances of finding a matching job. Robert (2014) found that an increase in the number of months spent on acquiring study-related work experience decreases the likelihood of horizontal mismatch. Non-study related activities, however, increase the odds of horizontal mismatch. It might increase the time needed to complete studies and not provide any additional skills relevant for employers.

Also the activities in which graduates are involved before entering college relate to horizontal mismatch. Compared to graduates who neither went to school nor worked, graduates who went to school, worked or combined both, are less likely to have a good job match (Boudarbat \& Chernoff, 2012). Those who worked before programme entrance are more likely to have a good match than graduates who only went to school before enrolling in university. Combining work with school is associated with the smallest probability of a good match. Another proxy for activities in which students are involved during their studies is whether they were enrolled in a part-time or full-time programme. Several studies found that graduates who studied full-time are more likely to obtain a job that matches their field compared to graduates who studied part-time (Boudarbat \& Chernoff, 2012; Farooq, 2011).

Finally, the perceived quality of a study programme can be used by employers as a signal of the quality of graduates' skills and competencies and affect school leavers' chances of ending up in a well-matching job. Kucel and Vilalta-Bufí (2012) demonstrated that those who attended a study programme that is considered academically prestigious by graduates face a reduced risk of becoming horizontally mismatched. In fact, the more employers are familiar with one's attended study programme, the lower the likelihood that a graduate is horizontally mismatched.

\subsubsection{Education Related Determinants at the Country Level}

The studies under review identified three factors that characterize a country's education system which determine horizontal mismatch; timing of academic specialization, vocational orientation and the strength of institutional linkages. Regarding the timing of academic specialization, late specialization might induce graduates more to switch to an unrelated occupation as the costs of not utilizing specific skills are lower than for graduates who specialized early. On the other hand, later specialization might offer students more time to acquire valuable information about their preferences and abilities by taking courses in different fields. Hence, later specialization conceivably provides students more insight into the probabilities of obtaining a field-related 
occupation given the acquisition of a specific field degree. Malamud (2011) found support for the second hypothesis as graduates who attended the Scottish education system, which is characterized by late specialization, are less likely to hold a job unrelated to the field of study compared to graduates from the English education system in which students specialize early. ${ }^{12}$

Also the extent to which an education system is vocationally oriented is strongly countrydependent. Wolbers (2003) defined countries as being more vocationally oriented when the share of upper secondary education students, who are enrolled in school-based or apprentice-type vocational education, is larger. Surprisingly, graduates are found to be more often mismatched in vocationally oriented countries. Nonetheless, the results are not significant. Levels et al. (2014) also found that the horizontal mismatch incidence is greater in countries with a strong vocational orientation (i.e. the share of vocational education offered as a combination of school-based education and learning at the workplace). Arguably, competition between graduates with a vocational degree is fiercer in countries with a large share of vocationally educated employees. Hence, the advantage of a vocationally oriented education system might vanish when the share of graduates with a vocational education increases.

However, the degree to which vocational education increases the likelihood of horizontal mismatch also depends on the strength of institutional linkages in a country. The strength of institutional linkages is reflected by the share of vocational education that is organized as a combination of school-based education and training at the workplace (Breen, 2005). Strong institutional linkages improve students' chances to obtain a job that matches their education through various channels. First, countries with strong institutional linkages provide employers an opportunity to teach students skills that are required by existing jobs (Andersen \& van de Werfhorst, 2010). Second, strong institutional linkages allow employers to design jobs in a way such that it meets the expected skills of vocational graduates. Levels et al. (2014) confirmed a positive relation between being vocationally educated and horizontal mismatch and showed that this relation is stronger in countries with strong institutional linkages.

This section has addressed the characteristics of graduates' study programme predicting the likelihood of horizontal mismatch. What can be noticed is that several education-related

\footnotetext{
${ }^{12}$ As a robustness check, Malamud (2011) investigated whether there are differences between the incidence of graduates ending up in an occupation that is unrelated to the field of study between England and Wales. The timing of academic specialization is similar in England and Wales and there appears to be no difference in the incidence of mismatched graduates. This supports the idea even further that the timing of specialization matters for students to acquire valuable information about their match quality in different fields of study.
} 
determinants of mismatch share similar properties, on the individual as well as on the country level. The field degree, level of education, attending vocational education, the type of vocational education, the vocational orientation of a country's education system and the strength of institutional linkages within a country all determine the degree to which graduates possess occupation-specific or general skills. Compared to graduates who have mainly acquired general skills through formal education, graduates who predominantly obtained specific skills are more likely to end up in a job that is closely related to their field degree. Although graduates with more general skills are more likely to be horizontally mismatched, based on the definitions identified in the literature, their skills are valued in a wider variety of jobs. The degree to which horizontal mismatch among graduates with general education is accompanied by skillunderutilization might therefore be smaller than most definitions actually suggests. According to the human capital theory, general skills increase workers' productivity in a wider range of occupations than specific skills (Becker, 1964). In fact, as Section 6 will point out, the wage penalties incurred by employees who received general education are less severe as opposed to those who received more occupation- specific education.

\subsection{Labour Market Related Determinants}

The previous section has discussed the effect of study programme characteristics on the likelihood that graduates experience horizontal mismatch. Once students complete formal education, labour market conditions as well as the state of the economy affect graduates' chances of finding a matching job. Graduates who face an economic recession upon labour market entry adjust their goals and are more likely to accept a job that does not match their field of education. Wolbers (2003) found that the aggregate unemployment rate in the year of labour market entry increases the odds of being horizontally mismatched. In contrast, Hensen et al. (2011) did not find a relation between the regional unemployment rate and horizontal mismatch.

Another measure for the state of the economy is the opportunity structure. The opportunity structure refers to the number and type of available vacancies and how well an employee's and other potential job candidates' skills match the requirements for a job (Witte \& Kalleberg, 1995). Witte and Kalleberg (1995) found that fluctuations in the opportunity structure negatively influence the probability for women to hold a job that matches their field degree, but not for men. 
Also the search duration to find the first job reflects the labour market conditions graduates face upon labour market entry. An increase in the number of months a graduate has been unemployed before finding the first job therefore increases the odds of being horizontally mismatched (Robert, 2014).

\subsection{Job Related Determinants}

Once graduates are employed, job-related factors influence the probability of being horizontally matched. One of the job-related factors predicting employees' horizontal match is how long an employee has been in his/her current job. Employees' tenure appears to be negatively related to horizontal mismatch (Witte \& Kalleberg, 1995; Wolbers, 2003). A potential explanation for this finding is that once employees find a job that matches their education and the returns to schooling meet a certain level, the employee will not be incentivized to change jobs (Witte \& Kalleberg, 1995). Another possible explanation is that as job tenure increases, employees accumulate firm-specific skills which are less attractive to other firms. Consequently, it is more difficult for mismatched employees with a longer tenure to search for a matching job outside the firm.

Besides job tenure, also employees' type of contract determines horizontal mismatch. Temporary jobs offer limited opportunities to acquire relevant work experience and productive skills as opposed to permanent employment. Given that employees with a temporary contract are expected to leave the company earlier, employers are generally reluctant to offer companyfunded training due to the shorter payback period of such investments (Becker, 1964; Booth, Francesconi \& Frank, 2002). Consequently, job-education mismatch can serve as a compensation for the lack of human capital that is typically gained through on-the-job training and work experience (Groot \& Maassen van den Brink, 1996). In fact, graduates with a temporary contract are more likely to be mismatched than employees with a permanent contract (Wolbers, 2003). Also employees in a part-time job are more likely to be mismatched compared to employees in a full-time job (Boudarbat \& Chernoff, 2012; Wolbers, 2003). Robert (2014) found that the odds of being horizontally mismatched are higher for employees with a permanent contract than for employees with a fixed term contract or self-employed employees. Arguably, employees might accept horizontal mismatch in return for job safety provided by a permanent contract. 
Variations in the prevalence of horizontal mismatch are also found across occupational groups and sectors. Bender and Roche (2013) indicated that self-employed workers are more likely to be severely mismatched than wage or salary workers. ${ }^{13}$ Whilst self-employed men are more likely to be mismatched predominantly due to working conditions, self-employed women tend to accept horizontal mismatch mainly for family-related reasons. Witte and Kalleberg (1995) hypothesized more matches in white-collar occupations as the duties and requirements for such jobs, also in terms of the education acquired, are less specifically defined. The authors also expected employees in civil servants positions to have a good match more often due to the consistency of educational requirements resulting from state bureaucracy. Whilst no significant differences were found for men across the different types of occupations, women in white collar and civil service occupations were more likely to be well-matched than women in blue-collar jobs. Along similar lines, Farooq (2011) showed that employees in specialized occupations; managers, professionals and associate professionals are less likely to be horizontally mismatched than employees in elementary occupations.

Occupational groups are also characterized by how well vocational education is established within this occupation (Witte \& Kalleberg, 1995). Whether occupational groups are characterized by the so called 'cultures of training' is reflected by the ratio of trainees to the total number of employees in an occupational group. A large share of trainees would imply that training is standardized and occupation-specific instead of firm-specific which should result in better matches. A large proportion of apprentices relative to the total workforce in an occupational group positively relates to the probability of having a good match for men (Witte \& Kalleberg, 1995). This does not hold for women, which could potentially be explained by the limited variation of how well 'cultures of training' are established in the organizations in which women work. With respect to the sector in which individuals are employed, the likelihood of horizontal match is greater in the public sector than in the private sector (Wolbers, 2003). This

\footnotetext{
${ }^{13}$ Bender and Roche (2013) examined the robustness of their analyses by controlling for heterogeneity between the self-employed and wage and salary employees (choosing self-employment to obtain a better work-life balance or due to prior labour market experiences). Interacting these variables with self-employment did not significantly change the relation between being self-employed and the probability of being mismatched. The authors also checked whether the results change when managers are left out of the dataset. Employees who climb up the career ladder into management use skills that deviate from those acquired through formal education. Excluding managers, however, did not significantly change the results. Finally, the authors attempted to account for endogeneity as employees might select themselves into self-employment for instance because they were mismatched in a wage or salary job. The results are relatively robust to corrections for endogeneity.
} 
can be attributed to the fact that the public sector consists of all healthcare and educational organizations which, on average, employ more graduates who received vocationally oriented education.

With respect to firm characteristics, being employed in a large firm can provide a relatively large set of opportunities to find a matching job (Hamilton, 1987). Wolbers (2003) found that employees in larger firms are more likely to be well-matched. Contrariwise, Witte and Kalleberg (1995) found that the likelihood of horizontal mismatch for men increases with the size of the firm (Witte \& Kalleberg, 1995). Arguably, individuals employed in large firms might be more incentivized to accept horizontal mismatch due to higher wages, job security and other job advantages offered by large firms (Kalleberg \& van Buren, 1992). The authors provide another potential explanation for their findings; tasks are defined more narrowly in large firms as a result of the greater division of labour. Specialized jobs can elicit the feeling among employees that the skills acquired through formal education are not fully utilized.

Finally, the method to obtain a job influences an employee's chances of finding a job that matches the field degree. Possible methods encompass; responding to a job advertisement, directly contacting an employer, through a campus placement agency, through an employment agency and through a head hunter. Boudarbat and Chernoff (2012) found that only the method of finding a job through a campus placement agency increases the probability of finding a matching job.

\subsection{Individual Determinants}

Finally, several characteristics related to the individual influence employees' labour market outcomes. For instance, labour market prospects and outcomes are found to differ between men and women along various dimensions (Altonji \& Blank, 1999). This also holds for obtaining a job that matches one's field degree. Bender and Heywood (2011) demonstrate that males are more likely to be mismatched than females. Other studies provide evidence that females are more likely to be mismatched as opposed to their male counterparts (Farooq, 2011; Hensen et al., 2009). For men, mismatch is more likely to be the result of career-oriented reasons like pay and promotion opportunities or changing career interests, whilst women are more likely to report mismatch due to amenity or constraints reasons such as family-related reasons, the job location or working conditions (Bender \& Heywood, 2011; Robst, 2007b). Bender and Roche (2013) found that, ceteris paribus, in the wage and salary sector, women are less likely to be severely 
mismatched than their male counterparts. In contrast, self-employed women are more likely to be severely mismatched than self-employed men.

The probability of being horizontally mismatched also relates to employees' age (Bender \& Roche, 2013; Wolbers, 2003). Using a panel framework, Bender and Heywood (2011) demonstrated that an additional year since graduation is positively related to mismatch. Employees in their early career are most likely to make the transition from a state of mismatch to a state of match. This is consistent with the idea that mismatch is a result of employees' career evolution and not necessarily an indicator of labour market inefficiency. Besides the fact that career interests might change over time, the value of the stock of human capital accumulated through formal education depreciates over time and reinvesting in rapidly depreciating skills becomes less attractive as the length of the payback period shortens. Moreover, the skills acquired through vocational education become less relevant over time in the presence of technological changes (Witte \& Kalleberg, 1995). Hensen et al. (2009), on the other hand, found that employees' age is positively associated with holding a job that matches the field of education. Robert (2014) also found a negative relation between horizontal mismatch and age; however, this effect vanishes when the sample is reduced to respondents who left their first job. As the latter two studies use samples consisting of recent graduates, it is possible that it takes some employees more time to find an appropriate job upon labour market entry. After some point, however, the probability of becoming horizontally mismatched arguably increases.

In addition to gender and age, a substantial amount of studies indicate the presence of racial differentials in labour market outcomes (Altonji \& Blank, 1999). Empirical evidence suggests that compared to white employees, the likelihood of being horizontally mismatched is higher for Asian men and lower for black employees and Hispanics (Bender \& Roche, 2013; Robst, 2007a). ${ }^{14}$ Black employees are more likely to be mismatched because a related job was unavailable, whilst they are less likely to report mismatch as a result of the job conditions, changing career interests, or family-related reasons. Also native employees are less likely to be

\footnotetext{
${ }^{14}$ Robst (2007b) used the same dataset as Robst (2007a). With respect to the probability of horizontal mismatch, Robst (2007a) found, compared to white employees, a significant positive effect for Asian men, but no effect for women. Robst (2007b), however, found an overall positive effect for Asian employees, compared to white employees. In contrast to Robst (2007a), Robst (2007b) combined the samples of men and women. Separate analyses for men and women might have given the same results. Furthermore, where Robst (2007a) found a significant negative effect for black employees, Robst (2007b) found no significant differences between white and black employees.
} 
horizontally mismatched as opposed to immigrant workers (Boudarbat \& Chernoff, 2012; Hensen et al. 2011).

An individual factor that strongly predicts educational as well as labour market outcomes is individuals' ability. Boudarbat and Chernoff (2012) investigated whether graduates' ability affects their chances of finding a matching job. Graduates' grades are used here as a proxy for graduates' ability. Employers could use high grades as a signal for the quality of an individual's subject-related skills. Boudarbat and Chernoff (2012) found that graduates in lower grade categories are significantly less likely to find a job that relates to the field of study compared to graduates in the highest grade category. Similarly, Kucel and Vilalta-Bufí (2012) found that university graduates' grades in secondary education decreases the likelihood of horizontal mismatch.

Another strong predictor of educational as well as labour market outcomes is parental education. Prior research points at parents' educational background and its link with their offspring's schooling choices and subsequent educational attainment (e.g., Dustmann, 2004; Ermisch \& Francesconi, 2001; Haveman \& Wolfe, 1995). Consequently, parental background also relates to subsequent labour market outcomes such as wages (Dustmann, 2004). As such, one could hypothesize that parental education is positively related to being well-matched. Robert's (2014) findings partially support this hypothesis. Whilst graduates with high-educated parents (ISCED5-6) are less likely to be horizontally mismatched than counterparts whose parents received less education (ISCED 3-4), graduates with low-educated parents (ISCED1-2) do not seem to be disadvantaged compared to graduates with high-educated parents. ${ }^{15}$

In addition to individual-related determinants that are exogenously determined, individuals make choices that affect their labour market outcomes. The extent to which employees are willing to seek for a job outside the place of residence can affect the probability of education-job misatch. Büchel and van Ham (2003) demonstrated that German employees, who are spatially flexible, have better chances of obtaining a job that matches their level of education. However, Hensen et al. (2009) found that geographic mobility has a negative effect on the likelihood of being horizontally matched. Besides geographic job mobility, active job search behaviour or changing jobs can increase the likelihood of finding a matching job. However, Robert (2014) found that having left the first job has no significant effect on horizontal mismatch.

\footnotetext{
${ }^{15}$ Here, the parental education is measured by taking the highest level of education of either the mother or father.
} 
Moreover, intensive jobs shifts (the number of jobs a graduate had before participating in the survey) are associated with a greater chance of being horizontally mismatched. This might suggest that intensive job search merely reflects an instable labour market position. Employees, who have left their first job, are more likely to be horizontally mismatched in the current job when they were mismatched in the first job.

Finally, having a disability and marital status are also determinants of horizontal mismatch. Disabled employees face a higher chance of obtaining a job that does not match the attended field of education (Bender \& Heywood, 2011; Robst, 2007a). The difference between the disabled and the non-disabled is particularly evident when a job is accepted outside the field degree for the reason that a related job was not available (Robst, 2007a). For employees in their late career stage, Bender and Heywood (2011) found no effect. Regarding individuals' marital status, individuals who are not or have never been married are more likely to be mismatched than employees who are married (Bender \& Roche, 2013; Robst, 2007a). ${ }^{16}$

\footnotetext{
${ }^{16}$ In contrast to Robst (2007a), Robst (2007b) found that employees who have never been married are less likely to be mismatched. Those who have never been married are more likely to accept horizontal mismatch due to pay and promotion opportunities and because a job in the field degree was not available, but less likely to accept mismatch as a result of working conditions or family-related reasons.
} 
Table 3. Parameter Estimates of the Determinants of Horizontal Mismatch (= treated as the outcome variable in this table)

\begin{tabular}{|c|c|c|c|c|c|c|c|c|c|c|}
\hline \multirow{2}{*}{$\begin{array}{l}\text { Author (year } \\
\text { publication) }\end{array}$} & \multirow{2}{*}{$\begin{array}{l}\text { Country of study } \\
\text { and definition } \\
\text { used }^{a}\end{array}$} & & \multicolumn{8}{|c|}{ Education-related determinants - Individual level } \\
\hline & & & $\begin{array}{l}\text { Field } \\
\text { of } \\
\text { study }\end{array}$ & $\begin{array}{l}\text { Level of } \\
\text { educ. }\end{array}$ & $\begin{array}{l}\text { Voca- } \\
\text { tional } \\
\text { educ. }\end{array}$ & $\begin{array}{l}\text { Type of vocational } \\
\text { education (men/women) }\end{array}$ & $\begin{array}{l}\text { Work experience } \\
\text { during studies (ref. } \\
\text { cat.=no work } \\
\text { experience) }\end{array}$ & $\begin{array}{l}\text { Major activity } \\
\text { before entering } \\
\text { university (ref. } \\
\text { cat.=not } \\
\text { working/ } \\
\text { studying) }\end{array}$ & $\begin{array}{l}\text { Time } \\
\text { devoted to } \\
\text { studies (ref. } \\
\text { cat.=full- } \\
\text { time) }\end{array}$ & $\begin{array}{l}\text { Study pro- } \\
\text { gramme's } \\
\text { prestige as a } \\
\text { signal of } \\
\text { quality }\end{array}$ \\
\hline $\begin{array}{l}\text { Witte et al. } \\
\text { (1995) }\end{array}$ & Germany & $\mathrm{C}$ & & & & $\begin{array}{l}\text { Ref. cat=school-based } \\
\text { vocational education } \\
\text {-Industrial } \\
\text { apprenticeship: +/n.e. } \\
\text {-Commercial } \\
\text { apprenticeship: +/n.e. }\end{array}$ & & & & \\
\hline $\begin{array}{l}\text { Wolbers } \\
(2003)\end{array}$ & $\begin{array}{l}13 \\
\text { countries }^{\mathrm{b}}\end{array}$ & $\mathrm{D}$ & s.e. & - & & $\begin{array}{l}\text { Ref. cat. }=\text { no vocational } \\
\text { educ.: n.e. }\end{array}$ & & & & \\
\hline Robst (2007a) & United States & B & s.e. & - & & & & & & \\
\hline $\begin{array}{l}\text { Hensen et al. } \\
(2011)\end{array}$ & $\begin{array}{l}\text { The } \\
\text { Netherlands }\end{array}$ & B & s.e. & - & & & & & & \\
\hline $\begin{array}{l}\text { Bender et al. } \\
(2011)\end{array}$ & United States & B & s.e. & & & & & & & \\
\hline Farooq (2011) & Pakistan & $\mathrm{B}$ & s.e. & n.e. & & & & & Part-time:+ & \\
\hline $\begin{array}{l}\text { Malamud } \\
(2011)\end{array}$ & $\begin{array}{l}\text { England and } \\
\text { Scotland }\end{array}$ & $\mathrm{D}$ & s.e. & & & & & & & \\
\hline $\begin{array}{l}\text { Boudarbat et } \\
\text { al. (2012) }\end{array}$ & Canada & $\mathrm{B}$ & s.e. & - & & & & $\begin{array}{l}\text {-Studying: + } \\
\text {-Working: + } \\
\text {-Studying and } \\
\text { working: + }\end{array}$ & $\begin{array}{l}\text {-Part-time: } \\
+ \\
\text {-Mix part- } \\
\text { time and } \\
\text { full-time: }+\end{array}$ & \\
\hline $\begin{array}{l}\text { Kucel et al. } \\
(2012)\end{array}$ & Poland & A & s.e. & n.e. & n.e. & & Internship: n.e. & & & $\begin{array}{l}\text {-Employers } \\
\text { familiar: - } \\
\text {-Prestigious: - }\end{array}$ \\
\hline $\begin{array}{l}\text { Bender et al. } \\
(2013)\end{array}$ & United States & B & & - & & & & & & \\
\hline $\begin{array}{l}\text { Levels et al. } \\
(2014)\end{array}$ & 20 countries $^{\mathrm{c}}$ & $\mathrm{D}$ & & & - & & & & & \\
\hline Robert (2014) & $\begin{array}{l}\text { Hungary, } \\
\text { Poland, } \\
\text { Lithuania and } \\
\text { Slovenia }\end{array}$ & $\mathrm{A}$ & s.e. & & & & $\begin{array}{l}\text {-Study-related work } \\
\text { experience: - } \\
\text {-Not study-related } \\
\text { work experience: + }\end{array}$ & & & \\
\hline
\end{tabular}


Table 3 Continued

\begin{tabular}{|c|c|c|c|c|c|c|c|c|}
\hline \multirow{2}{*}{$\begin{array}{l}\text { Author (year of } \\
\text { publication) }\end{array}$} & \multirow{2}{*}{\multicolumn{2}{|c|}{$\begin{array}{l}\text { Country of study } \\
\text { and definition used }\end{array}$}} & \multicolumn{3}{|c|}{ Education-related determinants - Country level } & \multicolumn{3}{|c|}{ Labour market-related determinants } \\
\hline & & & $\begin{array}{l}\text { Time of academic } \\
\text { specialization (ref. } \\
\text { cat.=early } \\
\text { specialization) }\end{array}$ & $\begin{array}{l}\text { Vocational } \\
\text { orientation } \\
\text { education system }\end{array}$ & $\begin{array}{l}\text { Strength } \\
\text { institutional } \\
\text { linkages }\end{array}$ & $\begin{array}{l}\text { State of the } \\
\text { economy } \\
\text { (unemployment } \\
\text { rate) }\end{array}$ & $\begin{array}{l}\text { Opportunity structure }{ }^{\mathrm{d}} \\
\text { (men/women) }\end{array}$ & $\begin{array}{l}\text { Job search } \\
\text { duration }\end{array}$ \\
\hline $\begin{array}{l}\text { Witte et al. } \\
\text { (1995) }\end{array}$ & Germany & $\mathrm{C}$ & & & & & $\begin{array}{l}\text { Ratio unemployed } \\
\text { employees to number } \\
\text { of available vacancies } \\
\text { for a specific } \\
\text { occupational group: } \\
\text { n.e./+ }\end{array}$ & \\
\hline Wolbers (2003) & $\begin{array}{l}13 \\
\text { countries }^{b}\end{array}$ & $\mathrm{D}$ & & $\begin{array}{l}\text {-Share of upper } \\
\text { secondary students } \\
\text { in school-based } \\
\text { vocational } \\
\text { education: + } \\
\text {-" in apprenticeship } \\
\text { type vocational } \\
\text { education: } \text { n.e. }\end{array}$ & & + & & \\
\hline $\begin{array}{l}\text { Hensen et al. } \\
(2011)\end{array}$ & The Netherlands & B & & & & n.e. & & \\
\hline $\begin{array}{l}\text { Malamud } \\
(2011)\end{array}$ & $\begin{array}{l}\text { England and } \\
\text { Scotland }\end{array}$ & $\mathrm{D}$ & $\begin{array}{l}\text { Late specialization: } \\
\text { - }\end{array}$ & & & & & \\
\hline $\begin{array}{l}\text { Levels et al. } \\
\text { (2014) }\end{array}$ & 20 countries $^{\mathrm{c}}$ & $\mathrm{D}$ & & $\begin{array}{l} \\
\frac{\text { Interaction }}{\text { vocational }} \\
\text { orientation } \\
\text { ×vocational } \\
\text { education: n.e. }\end{array}$ & $\begin{array}{l}\text { Interaction } \\
\text { institutional } \\
\text { linkages } \times \\
\text { vocational } \\
\text { education: - }\end{array}$ & & & \\
\hline Robert (2014) & $\begin{array}{l}\text { Hungary, Poland, } \\
\text { Lithuania and } \\
\text { Slovenia }\end{array}$ & A & & & & & & + \\
\hline
\end{tabular}


Table 3 Continued

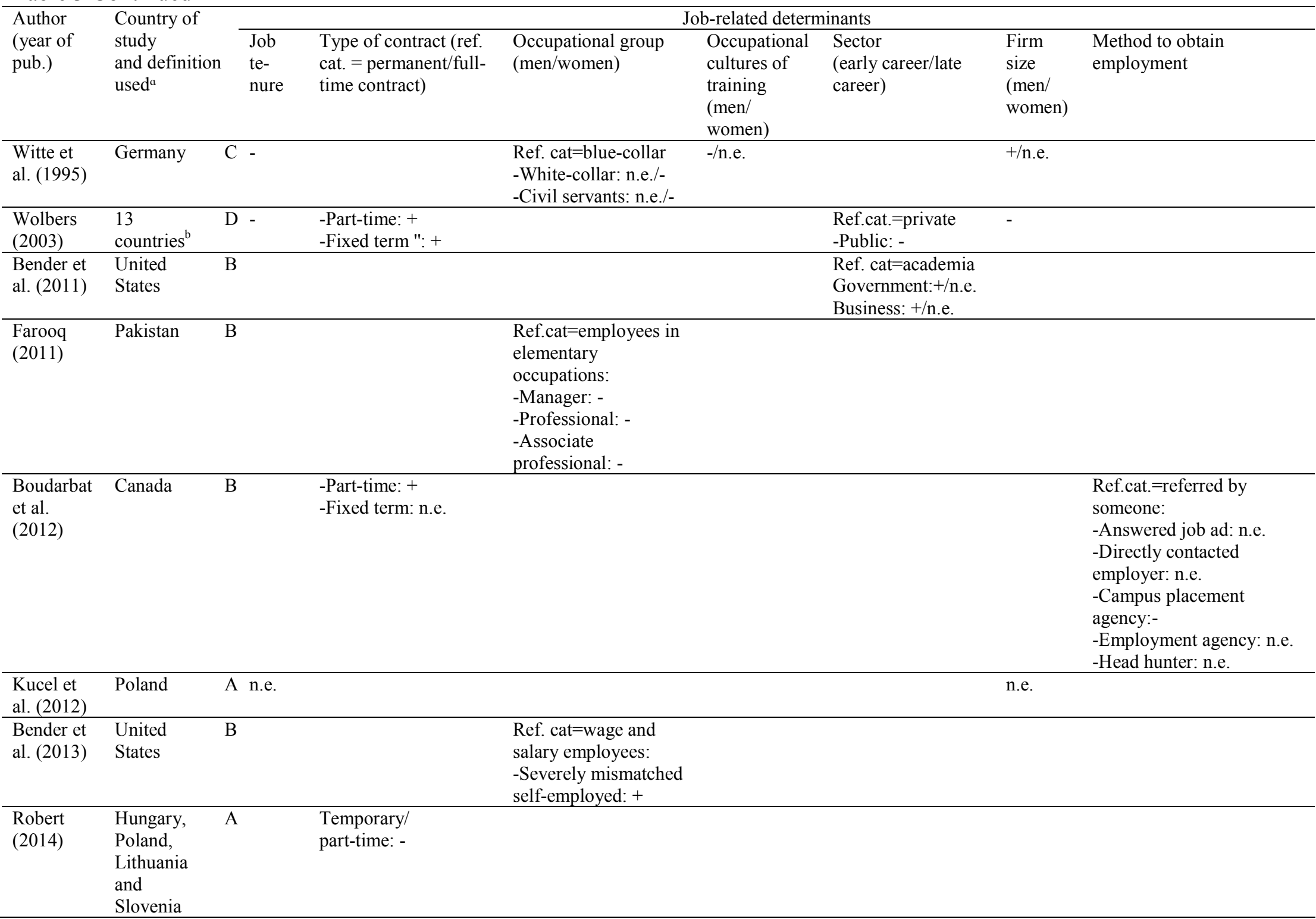


Table 3 Continued

\begin{tabular}{|c|c|c|c|c|c|c|c|c|c|c|}
\hline \multirow{2}{*}{$\begin{array}{l}\text { Author (year of } \\
\text { pub.) }\end{array}$} & \multirow{2}{*}{\multicolumn{2}{|c|}{$\begin{array}{l}\text { Country of study } \\
\text { and definition } \\
\text { used }^{a}\end{array}$}} & \multicolumn{8}{|c|}{ Individual-related determinants } \\
\hline & & & $\begin{array}{l}\text { Gender } \\
\text { (ref. cat.= } \\
\text { women) }\end{array}$ & Age & $\begin{array}{l}\text { Abi- } \\
\text { lity }\end{array}$ & Parental education & $\begin{array}{l}\text { Ethnicity } \\
\text { (men/women) }\end{array}$ & Job mobility & $\begin{array}{l}\text { Marital status } \\
\text { (ref. cat.= } \\
\text { married) }\end{array}$ & $\begin{array}{l}\text { Dis- } \\
\text { ability }\end{array}$ \\
\hline Witte et al. (1995) & Germany & $\mathrm{C}$ & + & + & & & & & & \\
\hline Wolbers (2003) & 13 countries $^{b}$ & $\mathrm{D}$ & + & + & & & & & & \\
\hline Robst (2007a) & United States & B & + & + & & & $\begin{array}{l}\text { Ref. cat.=white: } \\
\text {-Asians: +/n.e. } \\
\text {-Black: - } \\
\text {-Native } \\
\text { Americans:n.e. } \\
\text {-Hispanics: - }\end{array}$ & & + & + \\
\hline Robst (2007b) & United States & $\mathrm{B}$ & + & & & & & & & \\
\hline $\begin{array}{l}\text { Hensen et al. } \\
(2011)\end{array}$ & $\begin{array}{l}\text { The } \\
\text { Netherlands }\end{array}$ & $\mathrm{B}$ & - & - & & & $\begin{array}{l}\text { Ref. cat. }=\text { natives: } \\
\text {-Immigrants: }+\end{array}$ & Geographic:+ & & \\
\hline $\begin{array}{l}\text { Bender et al. } \\
\text { (2011) }\end{array}$ & United States & B & + & + & & & & & & n.e. \\
\hline Farooq (2011) & Pakistan & $\mathrm{B}$ & - & & & & & & & \\
\hline $\begin{array}{l}\text { Boudarbat et al. } \\
\text { (2012) }\end{array}$ & Canada & B & n.e. & n.e. & - & $\begin{array}{l}\text { Ref. cat.=parents with less } \\
\text { than secondary education: } \\
\text {-Secondary: n.e. } \\
\text {-Some postsecondary: n.e. } \\
\text {-Trade: + } \\
\text {-Postsecondary: n.e. } \\
\text {-Bachelor: n.e. } \\
\text {-Postgrad: n.e. }\end{array}$ & $\begin{array}{l}\text { Ref. cat. }=\text { natives: } \\
\text {-Immigrants: }+\end{array}$ & & & \\
\hline Kucel et al. (2012) & Poland & A & n.e. & n.e. & - & & & & & \\
\hline $\begin{array}{l}\text { Bender et al. } \\
\text { (2013) }\end{array}$ & United States & B & $\begin{array}{l}\text {-Wage } \\
\text { employees: + } \\
\text {-Self- } \\
\text { employed: - }\end{array}$ & + & & & $\begin{array}{l}\text { Ref. cat=white: } \\
\text {-Asians: n.e. } \\
\text {-Black: n.e. } \\
\text {-Hispanics: - }\end{array}$ & & + & \\
\hline Robert (2014) & $\begin{array}{l}\text { Hungary, } \\
\text { Poland, } \\
\text { Lithuania and } \\
\text { Slovenia }\end{array}$ & A & n.e. & n.e. & & $\begin{array}{l}\text { Ref. cat.=parents with } \\
\text { ISCED 5-6: } \\
\text {-ISCED 3-4: + } \\
\text {-ISCED 1-2: n.e. }\end{array}$ & & $\begin{array}{l}\text {-Number of } \\
\text { jobs: }+ \\
\text {-Left first } \\
\text { job: n.e. }\end{array}$ & & \\
\hline
\end{tabular}

Note: + indicates a positive relation between horizontal mismatch and the determinant, - indicates a negative relation, and n.e. indicates that no effect was found. a. Definition of horizontal mismatch: A. based on self-report on whether a specific field of education was required for the job B. based on respondents' assessment of the extent to which their current occupation is related to their attended field of education C. based on respondents' assessment of whether or not they have been trained for their current employment D. objective measure. b. The 13 countries comprise Austria, Belgium, Denmark, Spain, Finland, France, Greece, Hungary, Italy, Luxembourg, The Netherlands, Sweden and Slovenia. c. The 20 countries comprise Austria, Belgium, Czech Republic, Germany, Denmark, Spain, Finland, France, Greece, Hungary, Ireland, Italy, Luxembourg, the Netherlands, Norway, Poland, Sweden, Slovenia, Slovak Republic and the UK. 


\section{Effects of Horizontal Mismatch}

Table 4 provides an overview of the effects associated with horizontal mismatch. As Table 4 depicts, a substantial amount of economic research has been conducted on the effect of horizontal mismatch on employees' earnings. Social stratification research, on the other hand, has been concerned with the consequences of horizontal mismatch for employees' occupational status. Furthermore, the studies selected for our review have examined what horizontal mismatch implies for on-the-job search, training participation, job satisfaction and regret of the chosen field of study.

Most studies assessing the wage implications of horizontal mismatch compare wellmatched employees to their mismatched counterparts who hold the same field degree. Employees who are horizontally mismatched generally incur a wage penalty. Some employees, despite being mismatched, are still able to utilize some of the skills acquired through their field degree and, therefore, only incur small wage penalties (Bender \& Heywood, 2011; Bender \& Roche, 2013; Nordin, Persson \& Rooth, 2010; Robst, 2007b; Yakusheva, 2010). Robst (2007b) showed that whereas mismatched men receive a wage penalty of 11.9 percent, partially mismatched men only incur a wage loss of 2.9 percent. The wage penalties incurred by mismatched and partially mismatched women are 10.1 and 2.1 percent, respectively.

The wage effect differs across reasons for accepting horizontal mismatch (Robst, 2007a). The wage loss accompanied with horizontal mismatch because of the job location or familyrelated reasons, ranges from 18.1 to 29.3 percent for men and from 17.2 to 21.5 percent for women (Robst, 2007a). The pay penalties incurred due to the inability to find a matching job is 18.5 percent for females and 26.5 percent for men. In contrast, accepting horizontal mismatch because of pay and promotion opportunities is associated with a wage gain of 9.1 percent for women and 6.1 percent for men (Robst, 2007a). Hence, accepting horizontal mismatch does not always have negative wage consequences. Similarly, Zhu (2014) showed that 32.3 percent of the Chinese college graduates benefit from being horizontally mismatched as they receive a wage premium.

The wage effects also vary among employees in different types of employment. Compared to matched wage and salary workers, the severely mismatched self-employed incur wage penalties twice as large as mismatched wage and salary workers (Bender \& Roche, 
2013). ${ }^{17}$ In line with Robst (2007a), the greatest wage penalties are incurred when a matching job is unavailable. Mismatch also carries different wage penalties depending on employees' career stage. Bender and Heywood (2011) found greater wage penalties for mismatched employees later in their career stage than for those in the early stage of their career. As older mismatched employees are being compared with well-matched employees in the reward phase of their earnings profile, employees in later stages of their career face larger wage penalties in comparison to employees early in their career.

Zhu (2014) found relatively small wage penalties, namely, 1.2 percent for men and 1.5 percent for women. Zhu (2014) attributed these small wage losses to the strong emphasis of the Chinese education system on providing students with general skills. ${ }^{18}$ Such skills are believed to be transferable and rewarded in all occupations. Similarly, Nordin et al. (2012) argued that although employees who attended a field that mainly provides job-specific skills are less likely to be horizontally mismatched, they generally incur a larger wage penalty than employees who predominantly acquired general skills through their field of study. In fact, graduates with a degree in medicine, which is known to provide highly job-specific skills, suffer from the largest wage losses when experiencing horizontal mismatch (Zhu, 2014). Having a major in literature, on the other hand, provides rather general skills and is associated with the smallest wage penalties in the case of mismatch (Zhu, 2014).

In order to offset initial skill deficiencies, employees who are horizontally mismatched upon labour market entry might acquire additional skills on the job. Nordin et al. (2010) showed that the return to work experience for mismatched men is significantly greater than for wellmatched men. This supports the idea that mismatched employees reduce their initially incurred wage penalty by gaining relevant skills on the job. Likewise, Malamud (2010) showed that being mismatched in the first year after graduation yields a wage loss of 7 percentage points. However, compared to graduates who are matched upon labour market entry, initially mismatched employees do not significantly earn lower wages six years after graduation. This suggests that horizontal mismatch is only a temporary phenomenon.

\footnotetext{
${ }^{17}$ These results were obtained whilst including heterogeneity controls, that is, having children between the age of 6 and 11 and previous labour market experiences.

${ }^{18}$ The wage penalty associated with horizontal mismatch was found to be much larger with the OLS approach, namely, 5.9 percent. Given that the majority of studies use an OLS approach to estimate the wage effects of mismatch, the small wage penalties found by Zhu (2014) might merely be the result of employing a nonparametric model.
} 
According to the job search theory, mismatched employees might also try to improve their fit by changing jobs until an optimal match is reached (Jovanovic, 1979). The probability to look for another job appears to be larger for employees who are horizontally mismatched than for well-matched employees (Béduwé \& Giret, 2011; Malamud, 2010; Wolbers, 2003). Moreover, mismatched employees are more actively engaged in job search activities in countries with a low vocational orientation (Wolbers, 2003). This supports the view that vocational education functions as a safety net (Shavit \& Müller, 2000), reducing the risk of unemployment or ending up in unskilled employment. Some studies found no relation between horizontal mismatch and on-the-job search (Allen \& van der Velden, 2001; Shevchuk, Strebkov \& Davis, 2015).

A different strategy to cope with job-education mismatch is to participate in additional on-the-job training to offset the shortcoming of the skills acquired through initial education (Wolbers, 2003). The idea is that horizontally matched employees more optimally utilize their skills which reduces the need to invest in additional training. Unexpectedly, Wolbers (2003) found that horizontally mismatched school-leavers participate significantly less in additional training than their well-matched counterparts. However, the effect of job mismatches on training participation turns out to be positive in countries characterized by low shares of school-based vocational education and apprenticeship trainings. Arguably, graduates who have acquired general education more often receive training on the job to acquire job-specific skills which were not offered through formal education.

Where most economic studies focus on the wage consequences of mismatch, most social stratification research assess what mismatch entails for employees' occupational status. On average, mismatched employees have an occupational status that is lower than for well-matched employees (Wolbers, 2003). The loss in occupational status associated with mismatch is lower in countries characterized by an education system that is more vocationally oriented.

Various studies have also assessed the effect of horizontal mismatch on employees' level of job satisfaction. The effect of horizontal mismatch on job satisfaction decreases when controlling for certain job attributes such as having a permanent position or being employed in an organization with large internal labour markets. To put it differently, individuals appear to be willing to accept a job that does not match their field of study in exchange for a job that offers satisfactory perspectives such as job stability and professional development. Bender and Roche 
(2013) found that the effects on job satisfaction are less severe for self-employed employees than for wage and salary employees. This could indicate that despite the relative large wage penalties incurred by the mismatched self-employed, accepting horizontal mismatch in the selfemployment sector might offer certain job attributes that compensate for those wage penalties. Prior research indicates that self-employment offers, for instance, greater flexibility in working hours than wage and salary jobs (Benz \& Frey, 2008; Connelly, 1992).

Shevchuk et al. (2015) only found a negative association between horizontal mismatch and job satisfaction among women. Allen and van der Velden (2001) did not find any effect of horizontal mismatch on job satisfaction. However, skill underutilization does appear to negatively affect job satisfaction (Allen \& van der Velden, 2001). Also Béduwé and Giret (2011) found that the horizontal mismatch coefficient reduces in size when including an indicator for skill utilization at the workplace. Hence, it appears to be skill underutilization that leads employees to experience job dissatisfaction. As such, defining employees as horizontally mismatched is not always a perfect proxy for the degree to which employees underutilize fieldrelated skills. Finally, although it is not a direct assessment of employees' job satisfaction, Malamud (2010) found that mismatched employees are significantly less likely to obtain a job that is considered interesting.

Horizontal mismatch in graduates' first job also increases the likelihood of regretting the chosen study programme. Whilst mismatched graduates in Spain are 11.4 percentage points more likely to experience programme regret compared to their well-matched counterparts, in the Netherlands, horizontal mismatch increases the likelihood of regret by 16.2 percentage points (Kucel \& Vilalta-Bufí, 2013). As the Spanish education system provides students with rather general skills, horizontal mismatch is more common among Spanish graduates than among Dutch graduates. As regret is often based on a comparison across individuals and horizontal mismatch is rarer in the Netherlands, its effect on regret is more severe for the Dutch graduates. 
Table 4. Parameter Estimates of the Effects of Horizontal Mismatch (= treated as the predictor variable in this table)

\begin{tabular}{|c|c|c|c|c|c|c|c|c|}
\hline $\begin{array}{l}\text { Author } \\
\text { (year of } \\
\text { pub.) }\end{array}$ & $\begin{array}{l}\text { Country of } \\
\text { study } \\
\text { and definition } \\
\text { used }^{\mathrm{a}}\end{array}$ & & $\begin{array}{l}\text { Rate of return to horizontal mismatch } \\
\text { (male/female) }(\%)\end{array}$ & $\begin{array}{l}\text { On-the-job search } \\
\text { (ref. cat.=no } \\
\text { search) } \\
\text { (male/female) }\end{array}$ & $\begin{array}{l}\text { Training } \\
\text { participa- } \\
\text { tion (male/ } \\
\text { female) }\end{array}$ & $\begin{array}{l}\text { Occupa- } \\
\text { tional status } \\
\text { (male/ } \\
\text { female) } \\
\end{array}$ & $\begin{array}{l}\text { Job satisfaction } \\
\text { (male/ } \\
\text { female) }\end{array}$ & $\begin{array}{l}\text { Field study } \\
\text { regret (male/ } \\
\text { female) }\end{array}$ \\
\hline $\begin{array}{l}\text { Witte et al. } \\
\text { (1995) }\end{array}$ & Germany & $\mathrm{C}$ & $\begin{array}{l}\text {-Industrial apprenticeship: n.e. } \\
\text {-Commercial apprenticeship: n.e./+ } \\
\text {-School-based vocational educ.: n.e./+ }\end{array}$ & & & & & \\
\hline $\begin{array}{l}\text { Wolbers } \\
(2003)\end{array}$ & $\begin{array}{l}13 \\
\text { countries }^{b}\end{array}$ & D & & $\begin{array}{l}\text {-Overall: } \\
\text { Including } \\
\begin{array}{l}\text { HM } \times \text { vocational } \\
\text { orientation }\end{array} \\
\text { country: - }\end{array}$ & $\begin{array}{l}\text {-Overall:- } \\
\text { Including } \\
\underline{\mathrm{HM} \times} \\
\text { vocational } \\
\text { orientation } \\
\text { country: - } \\
\end{array}$ & $\begin{array}{l}\text {-Overall:- } \\
\text { Including } \\
\underline{\mathrm{HM} \times} \\
\text { vocational } \\
\text { orientation } \\
\text { country: - }\end{array}$ & & \\
\hline $\begin{array}{l}\text { Allen et al. } \\
(2001)\end{array}$ & $\begin{array}{l}\text { The } \\
\text { Netherlands }\end{array}$ & A & n.e. & n.e. & & & n.e. & \\
\hline $\begin{array}{l}\text { van de } \\
\text { Werfhorst } \\
(2002)\end{array}$ & $\begin{array}{l}\text { The } \\
\text { Netherlands }\end{array}$ & D & $\begin{array}{l}\text {-Overall average: }-3.48 \\
\text {-'Cultural' related competencies are } \\
\text { offered by employee's field of study and } \\
\text { are demanded by the job: n.e. } \\
\text {-'Economic' ": } 4.1 \\
\text {-'Communicative' ": } 7.1 \\
\text {-'Technical' " but not " (ref. cat.) - } 2.7\end{array}$ & & & & & \\
\hline $\begin{array}{l}\text { Robst } \\
(2007 a)\end{array}$ & $\begin{array}{l}\text { United } \\
\text { States }\end{array}$ & B & $\begin{array}{l}\text {-Overall:-10.2/-8.9 } \\
\text { HM by reason: } \\
\text {-Pay, promotion opportunities: } 6.1 / 9.1 \\
\text {-Working conditions: }-19.6 /-17.2 \\
\text {-Job location: }-29.3 /-21.1 \\
\text {-Changed career interests: }-8.3 / 4.7 \\
\text {-Family-related reasons: }-18.1 /-21.5 \\
\text {-No matching job available:-26.5/-18.5 }\end{array}$ & & & & & \\
\hline $\begin{array}{l}\text { Robst } \\
(2007 b)\end{array}$ & $\begin{array}{l}\text { United } \\
\text { States }\end{array}$ & B & $\begin{array}{l}\text {-Field not related: }-11.9 /-10.1 \\
\text {-Field somewhat related: }-2.9 /-2.1 \\
\end{array}$ & & & & & \\
\hline $\begin{array}{l}\text { Malamud } \\
(2010)\end{array}$ & $\begin{array}{l}\text { England } \\
\text { and } \\
\text { Scotland }\end{array}$ & D & $\begin{array}{l}-\mathrm{HM} \text { in first year after graduation: }-7.0 \\
-\mathrm{HM} \text { six years after graduation: n.e. }\end{array}$ & + & & & $\begin{array}{l}\text { Getting an interesting } \\
\text { job: - }\end{array}$ & \\
\hline $\begin{array}{l}\text { Mora } \\
(2010)\end{array}$ & Spain & $\mathrm{A}$ & & & & & & n.e. \\
\hline $\begin{array}{l}\text { Nordin et } \\
\text { al. }(2010)\end{array}$ & Sweden & D & $\begin{array}{l}\text {-HM: -19.5/-12.2 } \\
\text {-Weakly HM: -1.4/-2.9 } \\
\text {-HM+field gave specific skills:-19.8/-21.2 } \\
\text {-HM+field gave general skills:-18.3/-9.1 }\end{array}$ & & & & & \\
\hline
\end{tabular}




\begin{tabular}{|c|c|c|c|c|c|c|}
\hline & & & $\begin{array}{l}\text { Controlled for experience: } \\
\text {-HM: }-6.8 / 6.9\end{array}$ & & & \\
\hline $\begin{array}{l}\text { Yakushe- } \\
\text { va }(2010)\end{array}$ & $\begin{array}{l}\text { United } \\
\text { States }\end{array}$ & $\mathrm{D}$ & $\begin{array}{l}\text { Ref. cat.= degree has low relevance } \\
\text {-Highly relevant degree: } 21.2 \\
\text {-Medium relevant degree: } 6.3\end{array}$ & & & \\
\hline $\begin{array}{l}\text { Béduwé et } \\
\text { al. (2011) }\end{array}$ & France & $\mathrm{D}$ & $\begin{array}{l}\text {-HM+not VM: }-3.0 \\
\text {-HM+VM: }-11.0 \\
\text { Controlled for job characteristics: } \\
\text {-HM+ not VM: n.e. } \\
\text {-HM+ VM: }-7.0\end{array}$ & $\begin{array}{l}\text {-HM+ not VM: + } \\
\text {-HM+VM: }+\end{array}$ & $\begin{array}{l}\text {-HM+not VM:- } \\
\text {-HM+VM:- }\end{array}$ & \\
\hline $\begin{array}{l}\text { Bender et } \\
\text { al. }(2011)\end{array}$ & $\begin{array}{l}\text { United } \\
\text { States }\end{array}$ & B & $\begin{array}{l}\text { Early career }(<10 \text { years since degree }) \\
\text {-Partly/very HM: }-1.9 / \text { n.e. } \\
\text {-Very HM: }-6.9 /-7.7 \\
\text { Late career }(>25 \text { years since degree): } \\
\text {-Partly/very HM: }-4.5 /-11.5 \\
\text {-Very HM: }-21.1 / \text { n.e. }\end{array}$ & & & \\
\hline $\begin{array}{l}\text { Kucel et al. } \\
(2013)\end{array}$ & $\begin{array}{l}\text { Spain and } \\
\text { The } \\
\text { Netherlands }\end{array}$ & A & & & & $\begin{array}{l}\text {-Netherlands: } \\
+ \\
\text {-Spain: }+\end{array}$ \\
\hline $\begin{array}{l}\text { Bender et } \\
\text { al. }(2013)\end{array}$ & $\begin{array}{l}\text { United } \\
\text { States }\end{array}$ & B & $\begin{array}{l}\text { Ref. cat.=wage/salary matched employees } \\
\text { Wage/salary employees : } \\
\text {-Moderately HM: n.e. } \\
\text {-Severely HM: }-21.1 /-15.9 \\
\text { Self-employed: } \\
\text {-Moderately HM: }-8.8 /-17.1 \\
\text {-Severely HM: }-42.8 /-33.0\end{array}$ & & $\begin{array}{l}\text { Wage/salary } \\
\text { employees: } \\
\text {-Moderately HM:-/- } \\
\text {-Severely HM:-/- } \\
\text { Self-employed: } \\
\text {-Moderately HM:-/- } \\
\text {-Severely HM:-/- }\end{array}$ & \\
\hline Zhu (2014) & China & $\mathrm{B}$ & $-1.17 /-1.45$ & & & \\
\hline $\begin{array}{l}\text { Shevchuk } \\
\text { et al. } \\
\text { (2015) }\end{array}$ & Russia & B & $\begin{array}{l}\text {-Overall: -/- } \\
\text { Controlled for caregiving (CA): } \\
- \text { HM+CA: n.e./- } \\
\text {-HM+not CA: -/- }\end{array}$ & $\begin{array}{l}\text {-Overall: n.e. } \\
\text { Controlled for } \\
\text { caregiving }(\mathrm{CA}) \text { : } \\
-\mathrm{HM}+\mathrm{CA}: \text { n.e. } /+ \\
-\mathrm{HM}+\text { not CA: } \\
\text { n.e. }\end{array}$ & $\begin{array}{l}\text {-Overall: n.e./- } \\
\text { Controlled for } \\
\text { caregiving (CA): } \\
\text {-HM+CA: -/- } \\
\text { HM+not CA: n.e./- }\end{array}$ & \\
\hline
\end{tabular}

Note: HM indicates horizontal mismatch, VM indicates vertical mismatch, + indicates a positive relation between HM and the outcome variable, - indicates a negative relation and assessment of the extent to which their current occupation is related to their attended field of education C. respondents' assessment of whether or not they have been trained for their current employment D. objective measure. b. The 13 countries comprise Austria, Belgium, Denmark, Spain, Finland, France, Greece, Hungary, Italy, Luxembourg, The Netherlands, Sweden and Slovenia. 


\section{Conclusion and Discussion}

Relying on a systematic literature review, the aim of this paper is to address how prevalent horizontal mismatch is and to what extent it contributes to an inefficiently functioning labour market. In addition, we discussed the approaches in which the concept of horizontal mismatch has been operationalized in prior research and identified the factors that determine horizontal mismatch.

Several specifications of horizontal mismatch can be found in the literature, each yielding different incidence rates. The highest incidence rates are proposed by studies using an objective definition (e.g, Béduwé \& Giret, 2011; Malamud, 2011). On average, the different specifications generate incidence rates varying from 21 percent to 46 percent. The degree to which horizontal mismatch can be considered an undesirable phenomenon differs across mismatched individuals and depends among other things on the reason for accepting horizontal mismatch as well as on the degree to which skills are being underutilized. The reason for accepting a job that does not require employees' attended field of study may be demand as well as supply-related (Robst, 2007b). The source of horizontal mismatch is considered to be demand-related when a matching job is unavailable. Under this condition, horizontal mismatch can be considered a negative phenomenon given that students choose a field of study with the expectation of finding employment in field-related occupations (Betts, 1996; Holland, 1985). In fact, our review points out that horizontal mismatch often has unfavourable effects on employees' earnings, occupational status and job satisfaction (e.g., Bender \& Roche, 2013; van de Werfhorst, 2002; Wolbers, 2003). Horizontal mismatch also increases the likelihood of experiencing programme regret which is associated with substantial costs (Authors, 2016; Borghans \& Golsteyn, 2005; Kucel \& Vilalta-Bufi, 2013). From this perspective, horizontal mismatch may reveal that the process of skill formation and the allocation of skills on the labour market are sub-optimal.

The negative consequences induced by horizontal mismatch are more ambiguous, however, when the source of mismatch is supply-related. Supply-related reasons for accepting horizontal mismatch may pertain to pay and promotion opportunities or a change in career interests (Bender \& Heywood, 2011; Robst, 2007a; Robst, 2007b). The majority of these employees receive a wage premium over their well-matched counterparts, suggesting that horizontal mismatch does not necessarily indicate a severe underutilization of field-specific skills 
(Robst, 2007a; Zhu, 2014). Other employees might accept horizontal mismatch in exchange for favourable job attributes such as a permanent contract or a greater flexibility in working hours (Béduwé \& Giret, 2011; Benz \& Frey, 2008; Connelly, 1992). Hence, from an individual's perspective, accepting horizontal mismatch might be an economically rational decision under certain conditions. This also applies to employees in later stages of their career, especially in the presence of technological progress which induces skill obsolescence and the rise of new skill requirements (Bender \& Heywood, 2011; Witte \& Kalleberg, 1995). In fields that are sensitive to rapid changes, a greater value is being put on the skills acquired through work experience and on-the-job training. Whilst, from an individual's view, accepting mismatch can be economically rational, horizontal mismatch might still reflect an economic loss to society. This is the case when individuals' productivity level would be superior if a matching job or a different field of study would have been chosen. Whether horizontal mismatch in later career stages implies a labour market failure depends on whether employees gain new skills on the job and whether educational institutions adjust their curricula to meet labour market demands.

This review proposes that future research could benefit from a more uniform measure of horizontal mismatch. Besides the fact that each definition of horizontal mismatch yields varying incidence rates, the validity of the different measures that are identified in the literature can be called into question. Although individuals might be employed in similar jobs and acquired the same field degree, there might still be a discrepancy in the degree to which employees perceive the match between their job and their attended field of study. Moreover, defining employees as being poorly matched because their field degree was not a requirement for their job might also give problems of validity. Where some jobs only accept individuals who have acquired a specific degree, other jobs require a set of skills that is being offered by a wider range of fields.

Tracing the reasons for horizontal mismatches remains important, given the negative effects often associated with mismatch. Based on the findings of our review, several recommendations can be made to prevent horizontal skill mismatches. With respect to the design of education systems, mismatch can be prevented by providing students enough time to acquire valuable information on their preferences, abilities and job prospects offered by different field degrees (Malamud, 2011). Instead of delaying academic specialization, students might also benefit from services aimed at improving study choices before programme enrolment. Finally, strengthening institutional linkages may benefit vocational education graduates as it encourages 
employers to hire graduates with occupation-relevant skills (Levels et al., 2014). Strengthening institutional linkages also offers employers the opportunity to provide students with skills that their organizations require which can greatly improve the match between skill demand and skill supply. 


\section{Appendix A. Overview of the Selected Studies}

\begin{tabular}{|c|c|c|c|c|c|c|c|}
\hline & $\begin{array}{l}\text { Author } \\
\text { (year of } \\
\text { pub.) }\end{array}$ & Country of study & $\begin{array}{l}\text { Data source, type of } \\
\text { data and year of data } \\
\text { collection }\end{array}$ & Sample population & Statistical method & $\begin{array}{l}\text { Determinants of horizontal } \\
\text { mismatch subject to } \\
\text { examination }\end{array}$ & $\begin{array}{l}\text { Effects of } \\
\text { horizontal } \\
\text { mismatch } \\
\text { subject to } \\
\text { examination } \\
\end{array}$ \\
\hline 1 & $\begin{array}{l}\text { Witte \& } \\
\text { Kalleberg } \\
(1995)\end{array}$ & Germany & $\begin{array}{l}\text { German } \\
\text { Socioeconomic Panel } \\
\text { (GSOEP) - cross- } \\
\text { sectional - 1984-1990 }\end{array}$ & $\begin{array}{l}\text { Representative } \\
\text { household panel (final } \\
\text { sample for models of } \\
\text { mismatch determinants: } \\
\text { men: } \mathrm{n}=1,008 \text {; women: } \\
\mathrm{n}=637 \text {. Final sample } \\
\text { for models of mismatch } \\
\text { effects: } \text { men: } \mathrm{n}=1,881 \text {; } \\
\text { women: } \mathrm{n}=1,207 \text { ). }\end{array}$ & $\begin{array}{l}\text {-Logistic regression } \\
\text { to examine } \\
\text { determinants } \\
\text {-OLS regression to } \\
\text { examine effects }\end{array}$ & $\begin{array}{l}\text {-Type of vocational education } \\
\text {-Opportunity structure } \\
\text {-Job tenure } \\
\text {-Occupational group } \\
\text {-Firm size } \\
\text {-Occupation 'cultures of } \\
\text { training' } \\
\text {-Gender } \\
\text {-Age }\end{array}$ & Wage \\
\hline 2 & $\begin{array}{l}\text { Allen \& } \\
\text { van der } \\
\text { Velden } \\
(2001)\end{array}$ & The Netherlands & $\begin{array}{l}\text { Data were collected } \\
\text { for the project 'Higher } \\
\text { Education and } \\
\text { Graduate Employment } \\
\text { in Europe' - cross- } \\
\text { sectional - } 1998\end{array}$ & $\begin{array}{l}\text { Tertiary education } \\
\text { graduates who graduated } \\
\text { in } 1990 / 1991 \text { and held a } \\
\text { job of at least } 12 \text { hours } \\
\text { per week at the time of } \\
\text { the survey (final sample: } \\
\mathrm{n}=2,460 \text { ). }\end{array}$ & $\begin{array}{l}\text {-OLS: wage effects } \\
\text {-Logistic regression: } \\
\text { effect on on-the-job } \\
\text { search and job } \\
\text { satisfaction }\end{array}$ & & $\begin{array}{l}\text {-Wage } \\
\text {-On-the-job } \\
\text { search } \\
\text {-Job } \\
\text { satisfaction }\end{array}$ \\
\hline 3 & $\begin{array}{l}\text { van de } \\
\text { Werfhorst } \\
\text { (2002) }\end{array}$ & The Netherlands & $\begin{array}{l}\text { Survey from The } \\
\text { Netherlands Institute } \\
\text { for Social Research } \\
\text { (SCP) - time series - } \\
\text { 1991,1995 }\end{array}$ & $\begin{array}{l}\text { Employed individuals } \\
\text { aged 21-64 years with a } \\
\text { minimum of } 15 \text { working } \\
\text { hours per week (final } \\
\text { sample: } \mathrm{n}=6,373 \text { ). }\end{array}$ & $\begin{array}{l}\text { OLS regression: } \\
\text { wage effects }\end{array}$ & & Wage \\
\hline 4 & $\begin{array}{l}\text { Wolbers } \\
\text { (2003) }\end{array}$ & $\begin{array}{l}\text { Austria, } \\
\text { Belgium, } \\
\text { Denmark, Spain, } \\
\text { Finland, France, } \\
\text { Greece, } \\
\text { Hungary, Italy, } \\
\text { Luxembourg, } \\
\text { The Netherlands, } \\
\text { Sweden and } \\
\text { Slovenia. }\end{array}$ & $\begin{array}{l}2000 \text { ad hoc module of } \\
\text { the European Labour } \\
\text { Force Survey (EU LFS } \\
2000 \text { ) - cross-sectional } \\
-2000\end{array}$ & $\begin{array}{l}\text { Individuals aged } 15-35 \\
\text { years who left formal } \\
\text { education within the past } \\
\text { five years (Finland, } \\
\text { Luxembourg, the } \\
\text { Netherlands and } \\
\text { Sweden) or ten years (all } \\
\text { other countries) years } \\
\text { (final sample: } \mathrm{n}= \\
36,268 \text { ). }\end{array}$ & $\begin{array}{l}\text {-Logistic regression } \\
\text { to examine } \\
\text { determinants } \\
\text {-Logistic regression: } \\
\text { effects }\end{array}$ & $\begin{array}{l}\text {-Field of study } \\
\text {-Level of education } \\
\text {-Type of vocational education } \\
\text {-State of the economy } \\
\text {-Job tenure } \\
\text {-Type of contract } \\
\text {-Firm size } \\
\text {-Sector } \\
\text {-Gender } \\
\text {-Age }\end{array}$ & $\begin{array}{l}\text {-On-the-job } \\
\text { search } \\
\text {-Training } \\
\text { participation } \\
\text {-Occupational } \\
\text { status }\end{array}$ \\
\hline
\end{tabular}




\begin{tabular}{|c|c|c|c|c|c|c|c|}
\hline 5 & $\begin{array}{l}\text { Robst } \\
(2007 a)\end{array}$ & United States & $\begin{array}{l}\text { National Survey of } \\
\text { College Graduates } \\
\text { (NSCG) from the } \\
\text { National Science } \\
\text { Foundation- cross } \\
\text { sectional - } 1993\end{array}$ & $\begin{array}{l}\text { Nationally } \\
\text { representative sample of } \\
\text { individuals in the United } \\
\text { States who indicated on } \\
\text { the } 1990 \text { Census to have } \\
\text { attained at least a } \\
\text { bachelor's degree (final } \\
\text { sample: } \mathrm{n}=124,063 \text { ). }\end{array}$ & $\begin{array}{l}\text {-Ordered logit } \\
\text { regression: } \\
\text { determinants } \\
\text {-OLS regression: } \\
\text { effects }\end{array}$ & $\begin{array}{l}\text {-Field of study } \\
\text {-Level of education } \\
\text {-Gender } \\
\text {-Age } \\
\text {-Ethnicity } \\
\text {-Having a disability } \\
\text {-Marital status }\end{array}$ & Wage \\
\hline 6 & $\begin{array}{l}\text { Robst } \\
(2007 b)\end{array}$ & United States & $\begin{array}{l}\text { National Survey of } \\
\text { College Graduates } \\
\text { (NSCG) from the } \\
\text { National Science } \\
\text { Foundation- cross } \\
\text { sectional - } 1993\end{array}$ & $\begin{array}{l}\text { Nationally } \\
\text { representative sample of } \\
\text { individuals in the United } \\
\text { States who have attained } \\
\text { at least a bachelor's } \\
\text { degree (final sample: } \mathrm{n}= \\
124,063 \text { ). }\end{array}$ & $\begin{array}{l}\text {-Logit regression: } \\
\text { determinants } \\
\text {-OLS regression: } \\
\text { effects }\end{array}$ & $\begin{array}{l}\text { Robst }(2007 b) \text { uses the same } \\
\text { dataset and includes the same } \\
\text { regressors. Footnotes in the text } \\
\text { report when different } \\
\text { coefficients were obtained for } \\
\text { these variables. }\end{array}$ & Wage \\
\hline 7 & $\begin{array}{l}\text { Hensen et } \\
\text { al. (2009) }\end{array}$ & The Netherlands & $\begin{array}{l}\text { Two surveys from the } \\
\text { Research Centre for } \\
\text { Education and the } \\
\text { Labour Market } \\
\text { (ROA): Registration of } \\
\text { Outflow and } \\
\text { Destination of } \\
\text { Graduates (RUBS) and } \\
\text { HBO-monitor - time } \\
\text { series - 1996-2001 }\end{array}$ & $\begin{array}{l}\text { Individuals aged } 16-30 \\
\text { years, surveyed } 18 \\
\text { months after graduation, } \\
\text { who attended full-time } \\
\text { pre-secondary } \\
\text { vocational, secondary } \\
\text { vocational or higher } \\
\text { vocational education. } \\
\text { The individuals are in } \\
\text { paid employment (final } \\
\text { sample: } n=83,239) \text {. }\end{array}$ & $\begin{array}{l}\text { Logistic regression: } \\
\text { determinants }\end{array}$ & $\begin{array}{l}\text {-Field of study } \\
\text {-Level of education } \\
\text {-State of the economy } \\
\text {-Job density* } \\
\text {-Gender } \\
\text {-Age } \\
\text {-Ethnicity } \\
\text {-Job mobility }\end{array}$ & \\
\hline 8 & $\begin{array}{l}\text { Cosser } \\
(2010)\end{array}$ & South Africa & $\begin{array}{l}\text { Research Programme } \\
\text { on Human Resources } \\
\text { Development (HRD) - } \\
\text { time series - 2001, } \\
2002,2006\end{array}$ & (Final sample: 496,120). & Descriptive analysis & & \\
\hline 9 & $\begin{array}{l}\text { Malamud } \\
(2010)\end{array}$ & $\begin{array}{l}\text { England and } \\
\text { Scotland }\end{array}$ & $\begin{array}{l}\text { Survey conducted by } \\
\text { the British Department } \\
\text { of Employment: } 1980 \\
\text { National Survey of } \\
\text { Graduates and } \\
\text { Diplomates (NSGD) - } \\
\text { cross sectional - } \\
\text { 1986/1987 }\end{array}$ & $\begin{array}{l}\text { Scottish and English } \\
\text { university graduates who } \\
\text { obtained their BA } \\
\text { degree in } 1980 \text {. } \\
\text { Individuals were } \\
\text { employed full-time in } \\
\text { the first year after } \\
\text { graduation (final sample } \\
\text { NSGD: } \mathrm{n}= \pm 4,800) \text {. }\end{array}$ & $\begin{array}{l}\text { OLS regression: } \\
\text { effects }\end{array}$ & $\begin{array}{l}\text { Malamud (2011) uses the same } \\
\text { dataset and also examines the } \\
\text { effect of the timing of academic } \\
\text { specialization on horizontal } \\
\text { mismatch. Results were similar. }\end{array}$ & $\begin{array}{l}\text {-Wage } \\
\text {-Annual } \\
\text { earnings } \\
\text { growth* } \\
\text {-On-the-job } \\
\text { search } \\
\text { - Getting an } \\
\text { interesting } \\
\text { job }\end{array}$ \\
\hline
\end{tabular}




\begin{tabular}{|c|c|c|c|c|c|c|c|}
\hline 10 & $\begin{array}{l}\text { Mora } \\
(2010)\end{array}$ & Spain & $\begin{array}{l}\text { The Quality Assurance } \\
\text { Agency for seven } \\
\text { public universities in } \\
\text { Catalonia - cross- } \\
\text { sectional - } 2000\end{array}$ & $\begin{array}{l}\text { 1997/98 graduates aged } \\
23-33 \text { years from one of } \\
\text { the seven public Catalan } \\
\text { universities (final } \\
\text { sample } n>3500 \text { ) }\end{array}$ & $\begin{array}{l}\text { Probit regression and } \\
\text { two-step probit } \\
\text { regressions with } \\
\text { endogenous } \\
\text { regressor }\end{array}$ & & $\begin{array}{l}\text { Study } \\
\text { programme } \\
\text { regret }\end{array}$ \\
\hline 11 & $\begin{array}{l}\text { Nordin, et } \\
\text { al. }(2010)\end{array}$ & Sweden & $\begin{array}{l}\text { Data from Statistics } \\
\text { Sweden (SCB): } \\
\text { education data of } \\
\text { Swedish Register of } \\
\text { Education (UREG) } \\
\text { and income data of } \\
\text { National Tax Board } \\
\text { were added to register } \\
\text { of the total population } \\
\text { (RTB) - cross- } \\
\text { sectional - } 2003\end{array}$ & $\begin{array}{l}\text { Swedish-born } \\
\text { individuals aged } 28-39 \text {, } \\
\text { with a college } \\
\text { /university degree (final } \\
\text { sample men: } \mathrm{n}=67,607 \text {; } \\
\text { final sample females: } \mathrm{n} \\
=116,750 \text { ) }\end{array}$ & $\begin{array}{l}\text { OLS regression: } \\
\text { wage effects }\end{array}$ & & Wage \\
\hline 12 & $\begin{array}{l}\text { Yakusheva } \\
(2010)\end{array}$ & United States & $\begin{array}{l}\text { Survey conducted by } \\
\text { the U.S. department of } \\
\text { education: High } \\
\text { School and Beyond } \\
\text { (HS\&B) - longitudinal } \\
\text { 1982,1984,1986,1992 }\end{array}$ & $\begin{array}{l}\text { Sample of } 1980 \text { high } \\
\text { school sophomores with } \\
\text { some post-secondary } \\
\text { education ( } 4 \text { years at } \\
\text { most) (final sample: } n= \\
2,268 \text { ). }\end{array}$ & $\begin{array}{l}\text { OLS regression: } \\
\text { wage effects }\end{array}$ & & Wage \\
\hline 13 & $\begin{array}{l}\text { Béduwé \& } \\
\text { Giret } \\
\text { (2011) }\end{array}$ & France & $\begin{array}{l}\text { Generation } 98 \text { survey - } \\
\text { cross-sectional - } 2001\end{array}$ & $\begin{array}{l}\text { Graduates from } \\
\text { secondary vocational } \\
\text { educ. and first level of } \\
\text { higher education, } 3 \text { years } \\
\text { after graduation (final } \\
\text { sample: } n=21,780 \text { ). }\end{array}$ & $\begin{array}{l}\text {-OLS regression: } \\
\text { wage effects } \\
\text {-Probit regression: } \\
\text { effect on on-the-job } \\
\text { search and job } \\
\text { satisfaction }\end{array}$ & & $\begin{array}{l}\text {-Wage } \\
\text {-On-the-job } \\
\text { search } \\
\text {-Job } \\
\text { satisfaction }\end{array}$ \\
\hline 14 & $\begin{array}{l}\text { Bender \& } \\
\text { Heywood } \\
(2011)\end{array}$ & United States & $\begin{array}{l}\text { Survey of Doctorate } \\
\text { Recipients (SDR) - } \\
\text { panel - 1993,1995, } \\
1997,1999,2001,2003 \\
\text { and } 2006\end{array}$ & $\begin{array}{l}\text { PhD graduates in a (hard } \\
\text { or social) science, math, } \\
\text { or engineering (SME) } \\
\text { field and who reside in } \\
\text { the United States (final } \\
\text { sample }>200,000 \text { ). }\end{array}$ & $\begin{array}{l}\text {-Descriptive } \\
\text { analysis: } \\
\text { determinants } \\
\text {-Fixed effects } \\
\text { regression: effects }\end{array}$ & $\begin{array}{l}\text {-Field of study } \\
\text {-Sector } \\
\text {-Gender } \\
\text {-Age } \\
\text {-Disability } \\
\text {-Naturalized citizen* } \\
\text {-Noncitizen vs. noncitizen* }\end{array}$ & Wage \\
\hline 15 & $\begin{array}{l}\text { Farooq } \\
(2011)\end{array}$ & Pakistan & $\begin{array}{l}\text { Survey of Employed } \\
\text { Graduates (SEG) and } \\
\text { Labour Force Survey } \\
\text { (LFS) - time series - } \\
2010 \text { (SEG) and } \\
2006 / 2007,2008 / 2009 \\
\text { (LFS) }\end{array}$ & $\begin{array}{l}\text { Employed graduates } \\
\text { working in the formal } \\
\text { sector with a Bachelor's, } \\
\text { Master's or doctoral } \\
\text { degree. (final sample: } n \\
=513 \text { ). }\end{array}$ & $\begin{array}{l}\text { Logistic regression: } \\
\text { determinants }\end{array}$ & $\begin{array}{l}\text {-Field of study } \\
\text {-Level of education } \\
\text {-Time devoted to studies } \\
\text {-Occupational group } \\
\text {-Gender } \\
\text {-Socioeconomic background * } \\
\text {-Annual vs. semester system* }\end{array}$ & \\
\hline
\end{tabular}




\begin{tabular}{|c|c|c|c|c|c|c|}
\hline 16 & $\begin{array}{l}\text { Malamud } \\
(2011)\end{array}$ & $\begin{array}{l}\text { England and } \\
\text { Scotland }\end{array}$ & $\begin{array}{l}1980 \text { National Survey } \\
\text { of Graduates and } \\
\text { Diplomates (NSGD) } \\
\text { conducted by the } \\
\text { British Department of } \\
\text { Employment and } \\
\text { Universities Statistical } \\
\text { Record (USR) - cross- } \\
\text { section - 1986/1987 } \\
\text { (NSGD), 1972-1993 } \\
\text { (focus on 1980) (USR) }\end{array}$ & $\begin{array}{l}\text { NSGD: } 1980 \text { graduates } \\
\text { from Scottish and } \\
\text { English universities } \\
\text { USR: administrative } \\
\text { data on all students in } \\
\text { British universities and } \\
\text { Scottish universities } \\
\text { (final sample: } n= \\
\text { 15,337). }\end{array}$ & $\begin{array}{l}\text { OLS and two stage } \\
\text { least squares } \\
\text { regression: } \\
\text { determinants }\end{array}$ & $\begin{array}{l}\text { Timing of academic } \\
\text { specialization }\end{array}$ \\
\hline 17 & $\begin{array}{l}\text { Boudarbat } \\
\text { \& Chernoff } \\
(2012)\end{array}$ & Canada & $\begin{array}{l}\text { Follow up of Canadian } \\
\text { Graduates - Class of } \\
2000 \text { survey - cross- } \\
\text { section - } 2005\end{array}$ & $\begin{array}{l}\text { University graduates } \\
\text { (Bachelor and beyond), } \\
5 \text { years after graduation } \\
\text { (final sample: } n=9,335 \text { ) }\end{array}$ & $\begin{array}{l}\text { Logit regression: } \\
\text { determinants }\end{array}$ & $\begin{array}{l}\text {-Field of study } \\
\text {-Level of education } \\
\text {-Activities before university } \\
\text {-Time devoted to studies } \\
\text {-Type of contract } \\
\text {-Method to obtain job } \\
\text {-Gender } \\
\text {-Age } \\
\text {-Ethnicity } \\
\text {-Parental education } \\
\text {-Ability (grades) } \\
\text {-Family wealth* }\end{array}$ \\
\hline 18 & $\begin{array}{l}\text { Kucel \& } \\
\text { Vilalta- } \\
\text { Bufí (2012) }\end{array}$ & Poland & $\begin{array}{l}\text { HEGESCO survey for } \\
\text { Poland - cross-section } \\
\text { - } 2008\end{array}$ & $\begin{array}{l}\text { Graduates who received } \\
\text { their bachelor's or } \\
\text { master's degree } \\
\text { (ISCED5A) in } \\
\text { 2002/2003. Self- } \\
\text { employed and part-time } \\
\text { employees are excluded. } \\
\text { (final sample: } \mathrm{n}=692 \text { ) }\end{array}$ & $\begin{array}{l}\text { Logistic regression: } \\
\text { determinants }\end{array}$ & $\begin{array}{l}\text {-Field of study } \\
\text {-Level of education } \\
\text {-Vocational education } \\
\text {-Internship during studies } \\
\text {-Prestige of university } \\
\text {-Employers' familiarity with } \\
\text { programme } \\
\text {-Difficulty study programme* } \\
\text {-Freedom to compose study } \\
\text { programme* } \\
\text {-Broadness study programme* } \\
\text {-Job tenure } \\
\text {-Firm size } \\
\text {-Gender } \\
\text {-Age } \\
\text {-Ability (grades) } \\
\text {-Possessed competencies* }\end{array}$ \\
\hline
\end{tabular}




\begin{tabular}{|c|c|c|c|c|c|c|c|}
\hline 19 & $\begin{array}{l}\text { Bender \& } \\
\text { Roche } \\
\text { (2013) }\end{array}$ & United States & $\begin{array}{l}\text { Dataset from the US } \\
\text { National Science } \\
\text { Foundation (NSF): } \\
\text { National Survey of } \\
\text { College Graduates } \\
\text { (NSCG) - cross- } \\
\text { section - 2003 }\end{array}$ & $\begin{array}{l}\text { Employees with at least } \\
\text { a bachelor's degree in a } \\
\text { hard or social science, } \\
\text { technology, engineering, } \\
\text { or mathematics (STEM) } \\
\text { field (final sample: } n= \\
74,229)\end{array}$ & $\begin{array}{l}\text {-Ordered probit: } \\
\text { determinants } \\
\text {-OLS: wage effects } \\
\text {-Ordered probit: } \\
\text { effect on job } \\
\text { satisfaction }\end{array}$ & $\begin{array}{l}\text {-Level of education } \\
\text {-Occupational group } \\
\text {-Gender } \\
\text {-Age } \\
\text {-Ethnicity } \\
\text {-Marital status } \\
\text {-US citizenship* }\end{array}$ & $\begin{array}{l}\text {-Wage } \\
\text {-Job } \\
\text { satisfaction }\end{array}$ \\
\hline 20 & $\begin{array}{l}\text { Kucel \& } \\
\text { Vilalta- } \\
\text { Bufí (2013) }\end{array}$ & $\begin{array}{l}\text { Spain and } \\
\text { Netherlands }\end{array}$ & $\begin{array}{l}\text { REFLEX survey data - } \\
\text { cross-section - } 2005\end{array}$ & $\begin{array}{l}\text { 1999/2000 Tertiary } \\
\text { graduates (final sample } \\
\text { Spain: } \mathrm{n}=2,777 \\
\text { Netherlands: } \mathrm{n}=2,683 \text { ) }\end{array}$ & $\begin{array}{l}\text { Logistic regression: } \\
\text { effect on study } \\
\text { programme regret }\end{array}$ & & $\begin{array}{l}\text { Study } \\
\text { programme } \\
\text { regret }\end{array}$ \\
\hline 21 & $\begin{array}{l}\text { Levels et } \\
\text { al. (2014) }\end{array}$ & 20 countries $^{b}$ & $\begin{array}{l}\text { European Union } \\
\text { Labour Force Survey } \\
\text { 2009 Ad Hoc Module } \\
\text { (EU LFS 2009) - } \\
\text { cross-sectional - } 2009\end{array}$ & $\begin{array}{l}\text { Individuals aged 15-34 } \\
\text { years with upper- } \\
\text { secondary and post- } \\
\text { secondary (non-tertiary) } \\
\text { education who graduated } \\
\text { between 1989-2009. } \\
\text { (final sample: } \mathrm{n}= \\
\text { 30,805) }\end{array}$ & $\begin{array}{l}\text { Multi-level logistic } \\
\text { regression: } \\
\text { determinants }\end{array}$ & $\begin{array}{l}\text {-Vocational education } \\
\text {-Vocational orientation } \\
\text { education system } \\
\text {-Strength institutional linkages } \\
\text {-Standardization of curricula } \\
\text { and outcomes* }\end{array}$ & \\
\hline 22 & $\begin{array}{l}\text { Robert } \\
(2014)\end{array}$ & $\begin{array}{l}\text { Hungary, Poland, } \\
\text { Lithuania and } \\
\text { Slovenia }\end{array}$ & $\begin{array}{l}\text { HEGESCO survey, } \\
\text { follow-up of REFLEX } \\
\text { project (same } \\
\text { questionnaire)-cross- } \\
\text { sectional - 2008/2009 }\end{array}$ & $\begin{array}{l}\text { Individuals who } \\
\text { graduated five years } \\
\text { before in } 2002 / 2003 \\
\text { (final sample: } \mathrm{n}=6,665 \text { ) }\end{array}$ & $\begin{array}{l}\text { Logistic regression: } \\
\text { determinants }\end{array}$ & $\begin{array}{l}\text {-Field of study } \\
\text {-Work experience during educ. } \\
\text {-Job search duration } \\
\text {-Type of contract } \\
\text {-Gender } \\
\text {-Age } \\
\text {-Job mobility } \\
\text {-Parental education }\end{array}$ & \\
\hline 23 & Zhu (2014) & China & $\begin{array}{l}2008 \text { Chinese College } \\
\text { Graduates' } \\
\text { Employment and } \\
\text { Work Skills Survey - } \\
\text { cross-sectional - } 2008\end{array}$ & $\begin{array}{l}2007 \text { Graduates from } 43 \\
\text { 4-year colleges in the } \\
\text { Shandong province } 6-12 \\
\text { months prior to survey } \\
\text { (final sample: } \mathrm{n}=5,879 \text { ) }\end{array}$ & $\begin{array}{l}\text { OLS regression and } \\
\text { nonparametric local } \\
\text { linear kernel } \\
\text { estimation: wage } \\
\text { effects }\end{array}$ & & Wage \\
\hline 24 & $\begin{array}{l}\text { Shevchuket } \\
\text { al. (2015) }\end{array}$ & Russia & $\begin{array}{l}\text { Online questionnaire } \\
\text { conducted by the } \\
\text { authors - cross- } \\
\text { sectional data - } 2011\end{array}$ & $\begin{array}{l}\text { Russian-language } \\
\text { internet freelancers with } \\
\text { a completed tertiary } \\
\text { degree } \\
\text { (final sample men: } n= \\
918 ; \text { women: } n=684 \text { ) }\end{array}$ & $\begin{array}{l}\text {-Ordered probit: } \\
\text { effects on wage and } \\
\text { job satisfaction } \\
\text {-Logistic regression: } \\
\text { effect on on-the-job } \\
\text { search }\end{array}$ & & $\begin{array}{l}\text {-Wage } \\
\text {-On-the-job } \\
\text { search } \\
\text {-Job } \\
\text { satisfaction }\end{array}$ \\
\hline
\end{tabular}

France, Greece, Hungary, Ireland, Italy, Luxembourg, the Netherlands, Norway, Poland, Sweden, Slovenia, Slovak Republic and the U.K a. Wave 1987 is used to estimate the incidence and determinants of horizontal match. As a robustness check, cross-sectional logistic regressions were estimated separately for each year from 1984 to 1990 . The estimated coefficients were consistent over the years. The wage regressions were estimated on the monthly gross earnings of 1984. 


\section{Appendix B. Strategy Used in Computerized Databases Search ERIC [DECEMBER 2015]}

- Keywords: ‘mismatch OR match OR fit’ AND ‘education OR study OR major OR program OR college’ AND ‘job OR employment OR work OR occupation OR labour OR labor' AND ‘field’ +pubyear:1995

- Limit results to 'Peer reviewed only'

\section{EBSCOhost EconLit [DECEMBER 2015]}

- Keyword: 'mismatch OR match OR fit' AND 'education OR study OR major OR program OR college’ AND ‘job OR employment OR work OR occupation OR labour OR labor' AND ‘field’ - Limit to: 'January 1995' to 'December 2015' within 'Select a Field (optional)'

- Source types: 'Academic Journals’

- Language: 'english'

\section{EBSCOhost SocINDEX [DECEMBER 2015]}

- Keyword: 'mismatch OR match OR fit' AND ‘education OR study OR major OR program OR college’ AND ‘job OR employment OR work OR occupation OR labour OR labor' AND 'field’ within 'Select a Field (optional)'

- Limit to: 'Scholarly (Peer Reviewed) Journals', 'January 1995' to 'December 2015'

- Language: 'english' 


\section{References}

Alba-Ramirez, A. (1993). Mismatch in the Spanish labor market: overeducation? Journal of Human Resources, 28(2), 259-278. doi:10.2307/146203

Allen, J, \& Van der Velden, R. (2001). Educational mismatches versus skill mismatches: effects on wages, job satisfaction, and on-the-job search. Oxford Economic Papers, 53(3), 434452. doi:10.1093/oep/gpu024

Altonji, J. G., \& Blank, R. M. (1999). Race and gender in the labor market. Handbook of labor economics, 3, 3143-3259. doi:10.1016/S1573-4463(99)30039-0

Andersen, R.T., \& Van de Werfhorst, H. G. (2010). Education and occupational status in 14 countries: the role of educational institutions and labour market coordination. The British Journal of Sociology, 61(2), 336-355. doi:10.1111/j.1468-4446.2010.01315.x

Authors. (2016). Blinded for review.

Becker, Gary (1964). Human Capital. Chicago: The University of Chicago Press.

Béduwé, C., \& Giret, J. (2011). Mismatch of vocational graduates: What penalty on French labour market? Journal of Vocational Behavior, 78(1), 68-79. doi:10.1016/j.jvb.2010.09.003

Bender, K. A, \& Roche, K. (2013). Educational mismatch and self-employment. Economics of Education Review, 34, 85-95. doi:10.1016/j.econedurev.2013.01.010

Benz, M., \& Frey, B. S. (2008). Being independent is a great thing: Subjective evaluations of self-employment and hierarchy. Economica, 75(298), 362-383. doi:10.1111/j.1468-0335.2007.00594.x

Betts, J. R. (1996). What do students know about wages? Evidence from a survey of undergraduates. Journal of Human Resources, 31(1), 27-56. doi:10.2307/146042

Booth, A. L., Francesconi, M., \& Frank, J. (2002). Temporary jobs: stepping stones or dead ends? The Economic Journal, 112(480), F189-F213. doi:10.1111/1468-0297.00043

Borghans, L., \& Golsteyn, B. (2005). De kwaliteit van de studiekeuze. De Arbeidsmarkt naar Opleiding en Beroep tot 2010, 93-119. Retrieved from http://roa.sbe.maastrichtuniversity.nl

Borghans, L. \& de Grip, A. (2000 (eds)). The Overeducated Employee? The Economics of Underutilization of Skills. Cheltenham. doi:10.1016/0272-7757(95)00041-0 
Boudarbat, B., \& Chernoff, V. (2012). Education-job match among recent Canadian university graduates. Applied Economics Letters, 19(18), 1923-1926. doi:10.1080/13504851.2012.676730

Breen, R. (2005). Explaining cross-national variation in youth unemployment market and institutional factors. European Sociological Review, 21(2), 125-134. doi:10.1093/esr/jci008

Büchel, F. (2002). The effects of overeducation on productivity in Germany - the firms' viewpoint. Economics of Education Review, 21(3), 263-275. doi:10.1016/s0272-7757(01)00020-6

Büchel, F., \& Van Ham, M. (2003). Overeducation, regional labor markets, and spatial flexibility. Journal of Urban Economics, 53(3), 482-493. doi:10.1016/s0094-1190(03)00008-1

Chevalier, A. (2003). Measuring over-education. Economica, 70(279), 509-531. doi:10.1111/1468-0335.t01-1-00296

Chevalier, A., \& Lindley, J. (2009). Overeducation and the skills of UK graduates. Journal of the Royal Statistical Society: Series A (Statistics in Society), 172(2), 307-337. doi:10.1111/j.1467-985x.2008.00578.x

Connelly, R. (1992). Self-employment and providing child care. Demography, 29(1), 17-29. doi: $10.2307 / 2061360$

Cosser, M. (2010). The skills cline: higher education and the supply-demand complex in South Africa. Higher Education, 59(1), 43-53. doi:10.1007/s10734-009-9231-z

Dolton, P.J., \& Silles, M.A. (2000). The effects of over-education on earnings in the graduate labour market. Economics of Education Review, 27(2), 125-139. doi:10.1016/j.econedurev.2006.08.008

Dolton, P., \& Vignoles, A. (2000). The incidence and effects of overeducation in the UK graduate labour market. Economics of Education Review, 19(2), 179-198. doi:10.1016/s0272-7757(97)00036-8

Duncan, G. J., \& Hoffman, S. D. (1981a). The economic value of surplus education. Economics of Education Review, 1(1), 75-86. doi:10.1016/0272-7757(81)90028-5

Duncan, G. J., \& Hoffman, S. D. (1981b). The incidence and wage effects of overeducation. Economics of Education Review, 1(1), 75-86. doi:10.1016/0272-7757(81)90028-5 
Dustmann, C. (2004). Parental background, secondary school track choice, and wages. Oxford Economic Papers, 56(2), 209-230. doi:10.1093/oep/gpf048

Egger, M., Zellweger-Zähner, T., Schneider, M., Junker, C., Lengeler, C., \& Antes, G. (1997). Language bias in randomised controlled trials published in English and German. The Lancet, 350(9074), 326-329. doi:10.1016/s0140-6736(97)02419-7

Enequist, G., Kahlroth, M., Mähler Lejon, H., Lönn, M., Rosengren, P., \& Wahlén, S. (2006). OECD Thematic Review of Tertiary Education - Country Background Report for Sweden. Retrieved from http://www.oecd.org/

Ermisch, J., \& Francesconi, M. (2001). Family matters: Impacts of family background on educational attainments. Economica, 68(270), 137-156. doi:10.1111/1468-0335.00239

Farooq, S. (2011). The Utilisation of Education and Skills: Incidence and Determinants among Pakistani Graduates. The Pakistan Development Review, 50(3), 219-244. Retrieved from http://pide.org.pk/pdr/index.php/pdr

Groeneveld, S., \& Hartog, J. (2004). Overeducation, wages and promotions within the firm. Labour Economics, 11(6), 701-714. doi:10.1016/j.labeco.2003.11.005

Groot, W., \& Maasen van den Brink, H. M. (1996). Overscholing en verdringing op de arbeidsmarkt. Economisch-Statistische Berichten, 81(4042), 74-77. Retrieved from http://economie.nl

Groot, W., \& Maasen van den Brink, H. M. (2000). Overeducation in the labor market: a metaanalysis. Economics of education review, 19(2), 149-158. doi:10.1016/S0272-7757(99)00057-6

Hamilton, S. F. (1987). Apprenticeship as a transition to adulthood in West Germany. American Journal of Education, 95(2), 314-345. doi:10.1086/444304

Hartog, J. (2000). Over-education and earnings: where are we, where should we go? Economics of Education Review, 19(2), 131-147. doi:10.1016/s0272-7757(99)00050-3

Haveman, R., \& Wolfe, B. (1995). The determinants of children's attainments: A review of methods and findings. Journal of Economic Literature, 33(4), 1829-1878. Retrieved from https://www.aeaweb.org/journals/jel

Heijke, H., Meng, C., \& Ris, C. (2003). Fitting to the job: the role of generic and vocational competencies in adjustment and performance. Labour economics, 10(2), 215-229. doi:10.1016/s0927-5371(03)00013-7 
Hensen, M. M., De Vries, M. R., \& Cörvers, F. (2009). The role of geographic mobility in reducing education - job mismatches in the Netherlands*. Papers in Regional Science, 88(3), 667-682. doi:10.1111/j.1435-5957.2008.00189.x

Holland, J.L. (1985). Vocational preference inventory. Consulting Psychologists Press. doi:10.1037/t09505-000

De Jong, J., \& Berger, J. (2006). OECD Thematic Review of Tertiary Education - Country Background Report for The Netherlands. Retrieved from http://www.oecd.org/ Jovanovic, B. (1979). Job matching and the theory of turnover. The Journal of Political Economy, 87(5), 972-990. doi:10.1086/260808

Kalleberg, A. L., \& Van Buren, M. E. (1992). Organizations and economic stratification: A cross-national analysis of the size-earnings relation. Research in Social Stratification and Mobility, 11, 61-93. Retrieved from http://www.journals.elsevier.com/research-in-social-stratification-and-mobility/

Kiker, B. F., Santos, M. C., \& De Oliveira, M. M.. (1997). Overeducation and undereducation: Evidence for Portugal. Economics of Education Review, 16(2), 111-125. doi:10.1016/s0272-7757(96)00040-4

Kucel, A., \& Vilalta-Bufí, M. (2012). Graduate labor mismatch in Poland. Polish Sociological Review, 3(179), 413-429. Retrieved from http://polish-sociological-review.eu/

Kucel, A., \& Vilalta-Bufí, M. (2013). Why do tertiary education graduates regret their study program? A comparison between Spain and the Netherlands. Higher Education, 65(5), 565-579. doi:10.1007/s10734-012-9563-y

Levels, M., van der Velden, R., \& Di Stasio, V. (2014). From school to fitting work: How education-to-job matching of European school leavers is related to educational system characteristics. Acta Sociologica, 57(4), 341-361. doi:10.1177/0001699314552807

Levin, H., Belfield, C., Muennig, P., \& Rouse, C. (2007). The costs and benefits of an excellent education for all of America's children (Vol. 9): Teachers College, Columbia University New York.

Levin, H. M., \& Rouse, C. E. (2012). The true cost of high school dropouts. The New York Times, A31. Retrieved from www.nytimes.com

Machin, S., \& McNally, S. (2007). Tertiary education systems and labour markets. Education and Training Policy Division, OECD. Retrieved from http://www.oecd.org/ 
Malamud, O. (2010). Breadth versus depth: The timing of specialization in Higher Education. Labour, 24(4), 359-390. doi:10.1111/j.1467-9914.2010.00489.x

Malamud, O. (2011). Discovering one's talent: learning from academic specialization. Industrial \& Labor Relations Review, 64(2), 375-405. doi:10.1177/001979391106400209

McGuinness, S. (2006). Overeducation in the labour market. Journal of Economic Surveys, 20(3), 387-418. doi:10.1111/j.0950-0804.2006.00284.x

McGuinness, S., \& Bennett, J. (2007). Overeducation in the graduate labour market: A quantile regression approach. Economics of Education Review, 26(5), 521-531. doi:10.1016/j.econedurev.2005.12.003

McGuinness, S., \& Sloane, P. J. (2011). Labour market mismatch among UK graduates: An analysis using REFLEX data. Economics of Education Review, 30(1), 130-145. doi:10.1016/j.econedurev.2010.07.006

McIntosh, S. (2005). Evidence on the balance of supply and demand for qualified employees. In S. Machin \& A. Vignoles (Eds.), What's the Good of Education? The Economics of Education in the UK (pp. 169-188). Princeton University Press.

Mora, T. (2010). Why do higher graduates regret their field of studies? Some evidence from Catalonia, Spain. Education Economics, 18(1), 93-109. doi:10.1080/09645290802018001

Nordin, M., Persson, I., \& Rooth, D. (2010). Education-occupation mismatch: Is there an income penalty? Economics of Education Review, 29(6), 1047-1059. doi:10.1016/j.econedurev.2010.05.005

Quintano, C., Castellano, R., \& D'Agostino, A. (2008). Graduates in economics and educational mismatch: the case study of the University of Naples 'Parthenope'1. Journal of Education and Work, 21(3), 249-271. doi:10.1080/13639080802214118

Robert, P. (2014). Job mismatch in early career of graduates under post-communism. International Journal of Manpower, 35(4), 500-513. doi:10.1108/ijm-05-2013-0113

Robst, J. (2007a). Education and job match: The relatedness of college major and work. Economics of Education Review, 26(4), 397-407. doi:10.1016/j.econedurev.2006.08.003

Robst, J. (2007b). Education, college major, and job match: Gender differences in reasons for mismatch. Education Economics, 15(2), 159-175. doi:10.1080/09645290701263070 
Rubb, S. (2003). Overeducation in the labor market: A comment and re-analysis of a metaanalysis. Economics of Education review, 22(6), 621-629. doi:10.1016/s0272-7757(02)00077-8

Shavit, Y., \& Muller, W. (2000). Vocational secondary education. European Societies, 2(1), 2950. doi:10.1080/146166900360710

Shevchuk, A., Strebkov, D., \& Davis, S. N. (2015). Educational mismatch, gender, and satisfaction in self-employment: The case of Russian-language internet freelancers. Research in Social Stratification and Mobility, 40, 16-28. doi:10.1016/j.rssm.2015.02.004

Sloane, P. J. (2003). Much ado About Nothing? What does the Overeducation Literature Really Tell us. In F. Büchel, A. de Grip \& A. Mertens (Eds.), Overeducation in Europe. Current Issues in theory and Policy (pp. 11-45). Cheltenham: Edward Elgar.

Smyth, R., McClelland, J., Lister, P., Steenhart, K., Sargison, A., Westwater, K., Green, N., \& Huntingdon, N. (2006). OECD Thematic Review of Tertiary Education - Country Background Report for New Zealand. Retrieved from http://www.oecd.org/

Spady, W.G. (1970). Dropouts from higher education: An interdisciplinary review and synthesis. Interchange, 1(1), 64-85. doi:10.1007/bf02214313

Tsang, M. (1987). The impact of underutilization of education on productivity: A case study of the US Bell companies. Economics of Education Review, 6(3), 239-254. doi:10.1016/0272-7757(87)90003-3

Where do college graduates work? A Special Focus on Science, Technology, Engineering and Math (July 10, 2014). Retrieved from: https://www.census.gov/dataviz/visualizations/stem/stem-html/

Van de Werfhorst, H. G. (2002). Fields of study, acquired skills and the wage benefit from a matching job. Acta Sociologica, 45(4), 286-303. doi:10.1080/000169902762022879

Verdugo, R. R., \& Verdugo, N. (1989). The impact of surplus schooling on earnings: Some additional findings. Journal of Human Resources, 24(4), 629-643. doi:10.2307/145998

Verhaest, D., \& Omey, E. (2006). The impact of overeducation and its measurement. Social Indicators Research, 77(3), 419-448. doi:10.1007/s11205-005-4276-6 
Witte, J.C., \& Kalleberg, A. L. (1995). Matching training and jobs: The fit between vocational education and employment in the German labour market. European Sociological Review, 11(3), 293-317. Retrieved from http://esr.oxfordjournals.org/

Wolbers, M. H. J. (2003). Job Mismatches and their Labour-Market Effects among SchoolLeavers in Europe. European Sociological Review, 19(3), 249-266. doi:10.1093/esr/19.3.249

Yakusheva, O. (2010). Return to college education revisited: Is relevance relevant? Economics of Education Review, 29(6), 1125-1142. doi:10.1016/j.econedurev.2010.06.006

Zhu, R. (2014). The impact of major-job mismatch on college graduates' early career earnings: evidence from China. Education Economics, 22(5), 511-528.

doi:10.1080/09645292.2012.659009 
TIER WORKING PAPER SERIES

TIER WP 16/02

(C) TIER 2016

ISBN 978-94-003-0109-2 